This is a pre-copy-editing, author-produced PDF of an article accepted for publication in Review of Financial Studies following peer review. The definitive publisher-authenticated version: Fernandes N. and Ferreira M. A. Insider Trading Laws and Stock Price Informativeness Review of Financial Studies (2009) 22(5): 1845-1887 is available online at: http://dx.doi.org/10.1093/rfs/hhn066 


\title{
Insider Trading Laws and Stock Price Informativeness
}

\author{
Nuno Fernandes \\ Universidade Católica Portuguesa \\ Miguel A. Ferreira \\ ISCTE Business School-Lisbon
}

\begin{abstract}
We investigate the relation between a country's first-time enforcement of insider trading laws and stock price informativeness using data from 48 countries over 1980-2003. Enforcement of insider trading laws improves price informativeness, as measured by firm-specific stock return variation, but this increase is concentrated in developed markets. In emerging market countries, price informativeness changes insignificantly after the enforcement, as the important contribution of insiders in impounding information into stock prices largely disappears. The enforcement does not achieve the goal of improving price informativeness in countries with poor legal institutions. It does turn some private information into public information, thereby reducing the cost of equity in emerging markets. (JEL G14, G38)
\end{abstract}

The costs and benefits of insider trading and the need for regulation are an ongoing question in the finance literature. One view is that insider trading makes an important contribution with regard to the timely and accurate incorporation of information into stock prices. That is, insider trading contributes to more informative stock prices, in that prices actually reflect the firm's true value (Manne, 1966; Carlton and Fischel, 1983).

An opposite view theorizes that insider trading crowds out information collection by outside investors by limiting the gains available to outside investors (Fishman and Hagerty, 1992). Market professionals devote fewer resources to collecting information once they know there is a high probability of trading with insiders who have superior knowledge. If the crowding-out effect (deterring others from obtaining information) dominates, insider trading can actually make stock prices informationally less efficient. Critics of insider trading also suggest that by increasing information asymmetries, insider trading discourages investment (Ausubel, 1990), depresses stock market participationand gives

The authors thank an anonymous referee, Matthew Spiegel (the editor), Utpal Bhattacharya, Jose Manuel Campa, and participants at the 2006 Western Finance Association and 2006 European Finance Association meetings for helpful comments. Address correspondence to Nuno Fernandes, Faculdade de Ciências Economicas e Empresariais, Palma de Cima, 1649-023 Lisboa, Portugal; telephone: +351.217.214.270; e-mail: nfernandes@fcee.ucp.pt.

(C) The Author 2008. Published by Oxford University Press on behalf of the Society for Financial Studies. All rights reserved. For permissions, please e-mail: journals.permissions@oxfordjournals.org. doi: $10.1093 / \mathrm{rfs} / \mathrm{hhn} 066$ 
rise to additional adverse selection problems and inefficient corporate behavior (Manove, 1989).

We address this question by investigating the impact of a country's first-time enforcement of insider trading laws on stock price informativeness around the world. The sample includes 48 countries, and the period is 1980-2003, when many countries started to enforce laws restricting insider trading. This sample allows us to explore a broad cross-section of countries, as well as the time series dynamics of price informativeness.

Our hypothesis is that stock prices become more informative after an initial enforcement of insider trading laws. Different types of informed market participants can make different contributions to information collection and incorporation of information into stock prices. We analyze the roles of the various market participants by exploring variations in countries' information and institutional environments.

There is empirical evidence that the enforcement of insider trading laws significantly reduces the country-level cost of equity (Bhattacharya and Daouk, 2002). The particular way that the enforcement of insider trading laws contributes to a reduction in the cost of capital remains an open issue. To date, there is little direct evidence on the relation between a firm's information environment and insider trading laws.

Bushman, Piotroski, and Smith (2005) document an increase in analyst coverage following first-time enforcement of insider trading restrictions, especially in emerging markets. While this evidence suggests a positive link between the information environment and insider trading law enforcement, the association is not clear-cut. Easley, O'Hara, and Paperman (1998) argue that analyst activity is not a good proxy for information-based trading because analysts are "showcasing devices" and do not have significant firm-specific information. In findings that are consistent with no firm-specific information in analyst activities, Piotroski and Roulstone (2004) and Chan and Hameed (2006) indicate that greater analyst coverage is associated with lower stock price informativeness. One implication of these results is that the quality of an information environment cannot be inferred just by looking at analyst coverage.

We add to the literature by testing whether first-time enforcement of insider trading laws is, in fact, consistent with the hypothesis of an improvement in stock price informativeness. We use firm-specific stock return variation (as a fraction of total variation) as the main metric for stock price informativeness, and confirm the findings using alternative metrics. French and Roll (1986) and Roll (1988) show that a significant portion of stock return variation is not explained by market movements and is unrelated to public announcements. They suggest that firm-specific return variation measures the rate of information incorporation into prices via trading. Accordingly, high firm-specific return variation indicates that the stock price is tracking its fundamental value more closely, and stock markets are more efficient. This line of reasoning is in the tradition of Grossman and Stiglitz (1980), who predict that improving the 
cost-benefit trade-off on private information collection leads to more extensive informed trading and to more informative pricing. ${ }^{1}$

Jin and Myers (2006) develop a theory linking management opportunism, transparency, and firm-specific return variation that supports this interpretation. They argue that transparency prevents insiders from hiding bad news (which smooths returns but requires that insiders absorb bad-news costs), allowing for unimpeded firm-specific return variation.

Recent empirical evidence supports this informational interpretation of firmspecific return variation. High levels of firm-specific return variation are associated with more efficient capital allocation; US industry-level evidence is provided by Durnev, Morck, and Yeung (2004) and Chen, Goldstein, and Jiang (2006) and international evidence by Wurgler (2000). Furthermore, US industries with high levels of firm-specific return variation have stock prices that are more informative about future earnings (Durnev et al., 2003). Cross-country patterns of firm-specific return variation correspond to likely patterns of price informativeness. Morck, Yeung, and Yu (2000) find low firm-specific return variation in emerging markets but high firm-specific stock return variation in developed markets. In addition, low levels of firm-specific return variation are explained by minimal shareholder protection and corporate opaqueness (Jin and Myers, 2006).

Our panel evidence suggests greater firm-specific return variation after the enforcement of insider trading laws. Event study analysis also provides evidence of an increase in firm-specific return variation around the enforcement date. This is consistent with the idea that insider trading can in fact crowd out information collection and constrain informed trading by outside investors. When insiders are barred from trading, stock price informativeness improves, as more agents are now willing to invest resources to learn about the firm. While these findings support a hypothesis that the lower cost of information leads to more informed trading, and hence more informative stock prices, this is not the entire story.

Contrary to the evidence found in developed markets, our results show that enforcement of insider trading laws in emerging markets is associated with an insignificant change (or even a reduction) in firm-specific return variation. Our evidence suggests that, in developed markets, insider trading is not significantly related to price discovery, but in emerging markets it has a very important role. That is, insider trading contributes differently to the incorporation of information into stock prices in developed and emerging markets.

In results consistent with our findings, Chakravarty and McConnell (1999) find that in the United States the effect of insider trades on stocks prices does not differ from the effect of noninsider trades, while Bhattacharya, Daouk,

1 The Grossman and Stiglitz (1980) argument suggests that in a market with many risky stocks, the ones with cheaper information about their fundamental values are more attractive to traders. Accordingly, traders acquire more information about these stocks and their prices are more volatile and more informative than the prices of stocks with more costly information. 
and Kehr (2000) report that insider trades do indeed influence stock prices in Mexico, causing them to fully incorporate firm-specific information before it is released publicly.

Our results show that the enforcement of insider trading laws affects price informativeness differently, depending on a country's infrastructure. The positive response of price informativeness to the enforcement of insider trading laws is concentrated in countries with a strong macro infrastructure in terms of the efficiency of the judicial system, investor protection, and financial reporting. In countries with weaker infrastructure and where insider trading plays an important role in the incorporation of information into stock prices, other informed market participants, such as analysts, cannot make up for the information lost with the disappearance of insider trading, so there is no improvement in overall stock price informativeness.

The informational interpretation of firm-specific return variation, however, is not without controversy. Limits to arbitrage, pricing errors, and noise also result in volatility. So, we further support our conclusions using other measures of price informativeness. We find that the enforcement of insider trading laws is similarly related to the measure of information flow of Llorente et al. (2002) and that stock prices convey more information about future earnings when insider trading laws are enforced in developed markets (but not in emerging markets). We also run a simulation that shows firm-specific stock return variation is higher when a return shock is timely incorporated into stock prices, which is more likely to occur upon initial enforcement. There is less firm-specific return variation when a return shock is smoothed out over time.

In a final piece of evidence, we investigate the relation between the cost of equity and enforcement and information. There is a negative relation between the cost of equity and enforcement, which is consistent with the findings reported in Bhattacharya and Daouk (2002). Furthermore, we find that more informative stock prices, as measured by firm-specific return variation, reduce the cost of equity by reducing the risk for the uninformed investor. The effect of stock price informativeness helps to explain in part the decline in the cost of equity that is associated with the enforcement of insider trading laws.

An important issue is how to reconcile our evidence that stock price informativeness does not improve in emerging markets, while Bhattacharya and Daouk (2002) find that the cost of equity declines significantly in these very same countries. Easley and O'Hara (2004) hypothesize that it is not only the quantity of information that affects the cost of capital but also its quality, in particular the distribution between public and private information. In their setting, the cost of capital is an increasing function of private information.

We provide evidence consistent with the Easley and O'Hara (2004) model prediction using the proportion of zero returns (Lesmond, Ogden, and Trzcinka, 1999) as a measure of the probability of informed trading. We find a positive relation between the cost of equity and the proportion of zero returns. In 
addition, we find a lower proportion of zero returns around the enforcement of insider trading laws in emerging markets.

These results provide a way to reconcile our finding that the enforcement of insider trading laws does not improve stock price informativeness in emerging markets, with the reduction in the cost of equity documented in Bhattacharya and Daouk (2002). The effect of the enforcement is to turn some of the private information into public information, thereby reducing the adverse selection problem of uninformed investors trading with informed investors and, consequently, the risk premium required by uninformed investors in emerging markets. Overall, enforcement in emerging markets seems to affect primarily the quality of information, but not the quantity of information.

One implication of our findings is that simply transporting rules from one economic environment to another can be unfruitful (Ball, 2001). Implementing and enforcing insider trading laws, without complementary changes in country infrastructure, can actually have some side effects. To achieve an improved overall information environment and most effectively lower the cost of capital, regulators must complement insider trading restrictions with other policy initiatives to encourage investment in the production of information and minimize crowding-out effects.

The remainder of the paper is organized as follows. Section 1 describes the measures of firm-specific stock return variation and the data. Section 2 presents our core evidence on the relation between first-time enforcement of insider trading laws and stock price informativeness. Section 3 provides supporting evidence using alternative measures of stock price informativeness, and robustness checks. Section 4 studies the relation between the cost of equity and the enforcement and information. Section 5 concludes.

\section{Data and Methodology}

We first describe the measures of stock price informativeness, the data sources, the sample construction, and the country-level control variables used in the analysis.

\subsection{Firm-specific stock return variation}

Our central dependent variable is firm-specific stock return variation (or idiosyncratic risk) for each country. Stock return innovations linked to common factors or market returns are the source of systematic risk. Idiosyncratic risk results from innovations that are specific to a stock. Our strategy to measure these risks is based on a regression of equity returns on the returns of the market factors.

In the market model, for each firm-year, the projection of a stock's excess return on the market is

$$
r_{j, t}=\alpha_{j}+\beta_{j} r_{m, t}+e_{j, t}=\alpha_{j}+\frac{\sigma_{j m}}{\sigma_{m}^{2}} r_{m, t}+e_{j, t},
$$


with $\mathrm{E}\left(e_{j, t}\right)=\operatorname{Cov}\left(r_{m, t}, e_{j, t}\right)=0$; where $r_{j, t}$ is the return of stock $j$ in month $t$ in excess of the risk-free rate; $r_{m, t}$ is the value-weighted excess local market return $r_{m, t}=\sum_{j} w_{j, t} r_{j, t}$, where $w_{j, t}$ is the weight of firm $j$ in month $t ; \sigma_{j m}=$ $\operatorname{Cov}\left(r_{j, t}, r_{m, t}\right)$; and $\sigma_{m}^{2}=\operatorname{Var}\left(r_{m, t}\right)$. Firm-specific return variation is estimated for each firm-year as

$$
\sigma_{j e}^{2}=\sigma_{j}^{2}-\frac{\sigma_{j m}^{2}}{\sigma_{m}^{2}} .
$$

We also calculate our measure of firm-specific return variation using a twofactor international model, as in Morck, Yeung, and Yu (2000), to include both the local and US market index returns:

$$
r_{j, t}=\alpha_{j}+\beta_{1 j} r_{m, t}+\beta_{2 j} r_{U S, t}+e_{j, t},
$$

with $\operatorname{Cov}\left(r_{m, t}, e_{j, t}\right)=\operatorname{Cov}\left(r_{U S, t}, e_{j, t}\right)=0 .^{2}$ The firm-specific return variation is estimated as

$$
\widehat{\sigma}_{j e}^{2}=\widehat{\sigma}_{j}^{2}-\widehat{C}_{j F}^{T} \widehat{V}_{F}^{-1} \widehat{C}_{j F},
$$

with $r_{F, t}=\left\{r_{m, t}, r_{U S, t}\right\}$ as the vector of excess factor returns; where $C_{j F}=$ $\operatorname{Cov}\left(r_{j, t}, r_{F, t}\right)$ is the vector of covariances of stock $j$ returns with the factors; and $V_{F}=\operatorname{Cov}\left(r_{F, t}^{T}, r_{F, t}\right)$ is the factor variance-covariance matrix.

From the absolute firm-specific return variation, $\sigma_{j e}^{2}$, we compute the relative firm-specific return variation, that is, the ratio of idiosyncratic volatility to total volatility, $\sigma_{j e}^{2} / \sigma_{j}^{2}$. This is precisely $1-R_{j}^{2}$ of Equations (1) or (3). Given the bounded nature of $R^{2}$, we conduct our tests using a logistic transformation of $1-R_{j}^{2}$ :

$$
\Psi_{j}=\log \left(\frac{1-R_{j}^{2}}{R_{j}^{2}}\right)=\log \left(\frac{\sigma_{j e}^{2}}{\sigma_{j}^{2}-\sigma_{j e}^{2}}\right) .
$$

Thus, our dependent variable $\Psi_{j}$ measures firm-specific stock return variation relative to marketwide variation, or lack of synchronicity with the market. One reason we scale firm-specific stock return variation by the total variation in returns is that firms in some countries are more subject to economy-wide shocks than others, and firm-specific events can be correspondingly more intense. We also do this for comparability with other research, such as Morck, Yeung, and Yu (2000).

\subsection{Alternative measures of stock price informativeness}

To substantiate our informational interpretation of the relation between the initial enforcement of insider trading laws and firm-specific return variation,

${ }^{2}$ When we check this specification by using the world market index instead of the US market index, the primary results are unchanged. 
we also test for this relation using alternative dependent variables that measure the level of information incorporated into stock prices.

We use an information measure suggested by Llorente et al. (2002), which is based on stock return autocorrelation conditional on trading volume. To construct the measure for each firm-year, we estimate the time series regression

$$
r_{j, t}=\alpha_{j}+\gamma_{j} r_{j, t-1}+\theta_{j} r_{j, t-1} V_{j, t-1}+e_{j, t},
$$

using weekly stock return and volume data; where $V_{j, t}$ is $\log$ turnover detrended by subtracting a 26-week moving average. The amount of information-based trading is given by the regression coefficient $\theta_{j}$ on the interaction variable. With this procedure, we have one observation of $\theta$ for each firm-year. Higher values of this variable indicate more information-based trading (as opposed to noise or liquidity trading). The intuition is that in periods of high volume, stocks with a high degree of information-based trading tend to display positive return autocorrelation.

We also confirm our interpretation of firm-specific return variation as a measure of stock price informativeness by considering the relation between an initial enforcement action and a measure of the extent to which stock prices incorporate information about future earnings. If firm-specific return variation reflects the incorporation of information about fundamentals into stock prices, then stock prices incorporate more information about future earnings. If firmspecific return variation reflects noise trading, however, such variation indicates stock prices are deviating from fundamental values, and consequently, stock prices incorporate little information about future earnings.

Following Durnev et al. (2003), we compute the future earnings return coefficient $(F E R C)$, which is given by the sum of the coefficients $\sum_{\tau=1}^{2} b_{\tau}$ on future changes in earnings in the regression

$$
r_{j, t}=a_{0}+b_{0} \Delta E_{j, t}+\sum_{\tau=1}^{2} b_{\tau} \Delta E_{j, t+\tau}+\sum_{\tau=1}^{2} d_{\tau} r_{j, t+\tau}+\epsilon_{j, t},
$$

where $r_{j, t}$ is the annual stock return of stock $j$, and $\Delta E_{j, t}$ is the annual change in net income before extraordinary items divided by the previous year's stock market capitalization. For each year around the enforcement date, we estimate the cross-sectional regression (7) in each country (with at least 10 firms).

\subsection{Data description}

The stock price and financial data for our study come from Datastream and Worldscope. Our sample begins with all companies in the Worldscope database from 1980 to 2003. We use this sample to construct our country-level measure of firm-specific stock return variation and other country-level control variables. 
In our total of 48 countries, 24 are developed markets and 24 are emerging markets.

Annual relative firm-specific stock return variation estimates over 1980-2003 are first calculated using the two-factor international model and monthly excess returns denominated in US dollars for each stock. We use monthly returns (instead of weekly or daily returns) to avoid the bias induced by nonsynchronous trading that is particularly prominent in emerging markets. Excess returns in US dollars are the differences between returns for each month $t$ and the riskfree rate (the three-month US Treasury-bill rate of return at the end of the prior month $t-1)$. Individual equity returns and country index returns come from Datastream, and US T-bill return data come from the Center for Research in Security Prices (CRSP).

We examine the robustness of our results using alternative estimators of the firm-specific return variation. The results are robust to the measure of firm-specific return variation in terms of frequency of returns (weekly instead of monthly), currency of returns (local currency instead of US dollars), sample period, asset pricing model (local market model instead of two-factor international model), and Scholes and Williams (1977) or French, Schwert, and Stambaugh (1987) adjustment for serial and cross-serial correlation in returns.

We eliminate firms with negative sales in a particular year and with total assets of under $\$ 100$ million to make firms across countries more comparable. Results for regressions using all firms or firms with total assets of \$10 million or more are similar. An additional filter is applied in the calculation of firmspecific return variation estimates. For each year $t$, firm-specific return variation is calculated for a stock only if the Datastream monthly file provides valid returns in every month of a year. We thus exclude the years a stock enters and leaves the sample. To avoid drawing spurious inferences from extreme values, we winsorize observations in the bottom $1 \%$ and top $1 \%$ of the individual firm-specific return variation distribution.

To conduct our country-level study, we aggregate $\Psi_{j}$ across firms for each country in each year. We use the median $\Psi_{j}$ as the main dependent variable. Equally weighted or value-weighted averages of $\Psi_{j}$ for each country produce similar results.

Table 1 reports summary statistics of annual country-level relative firmspecific return variation $\left(\sigma_{e}^{2} / \sigma^{2}\right)$ and its logistic transformation $(\Psi)$ estimated from a two-factor international model with US dollar-denominated monthly returns for each country. Panel A reports averages for developed markets and Panel B for emerging markets. There are a total of 821 country-year observations in 48 countries, with average relative firm-specific return variation across all countries of 0.561 . The average relative firm-specific return variation varies widely across countries, from a minimum of 0.274 in Sri Lanka to a maximum of 0.807 in the United States. As expected, relative firm-specific return variation is $5.6 \%$ higher in developed markets than in emerging markets. 


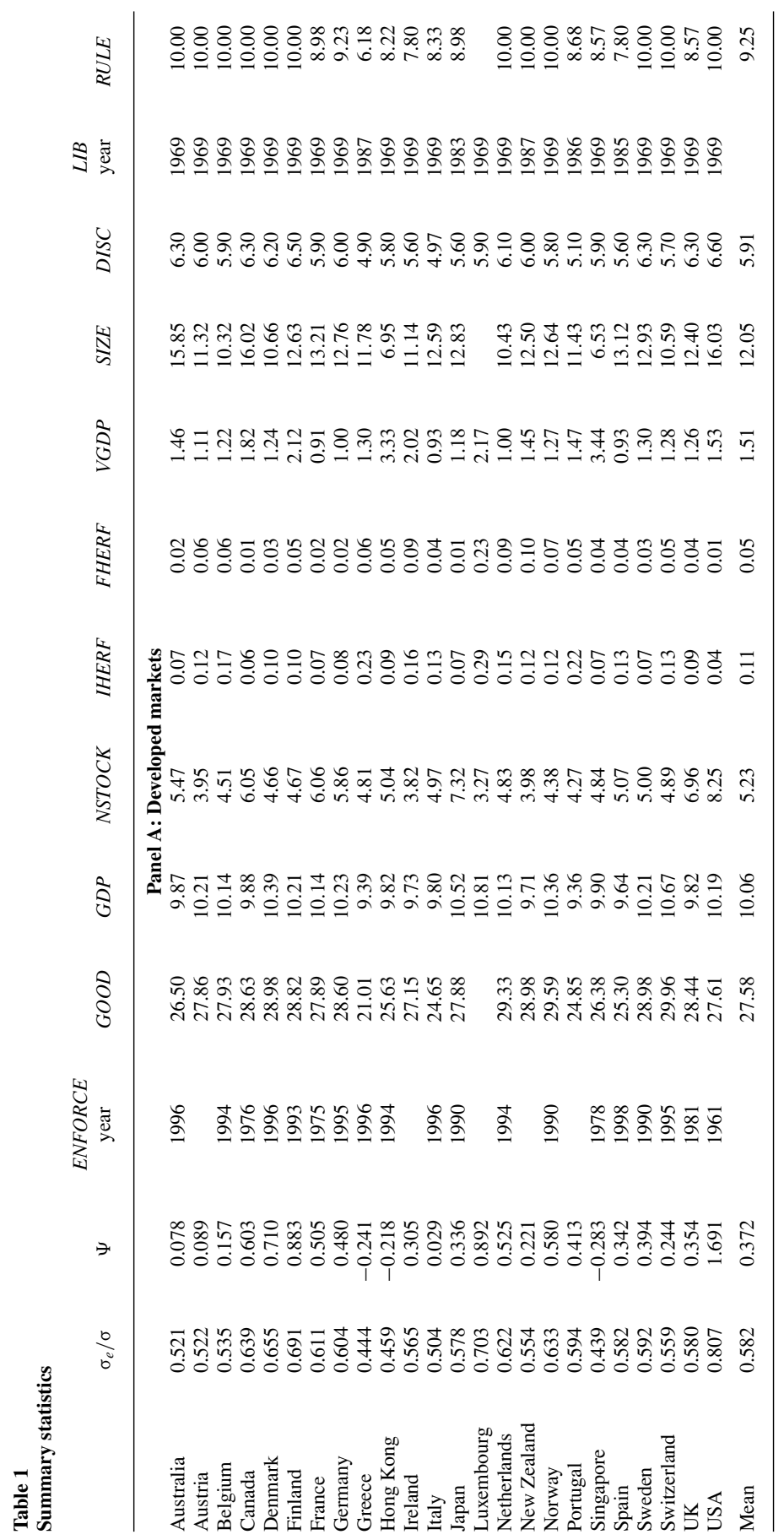




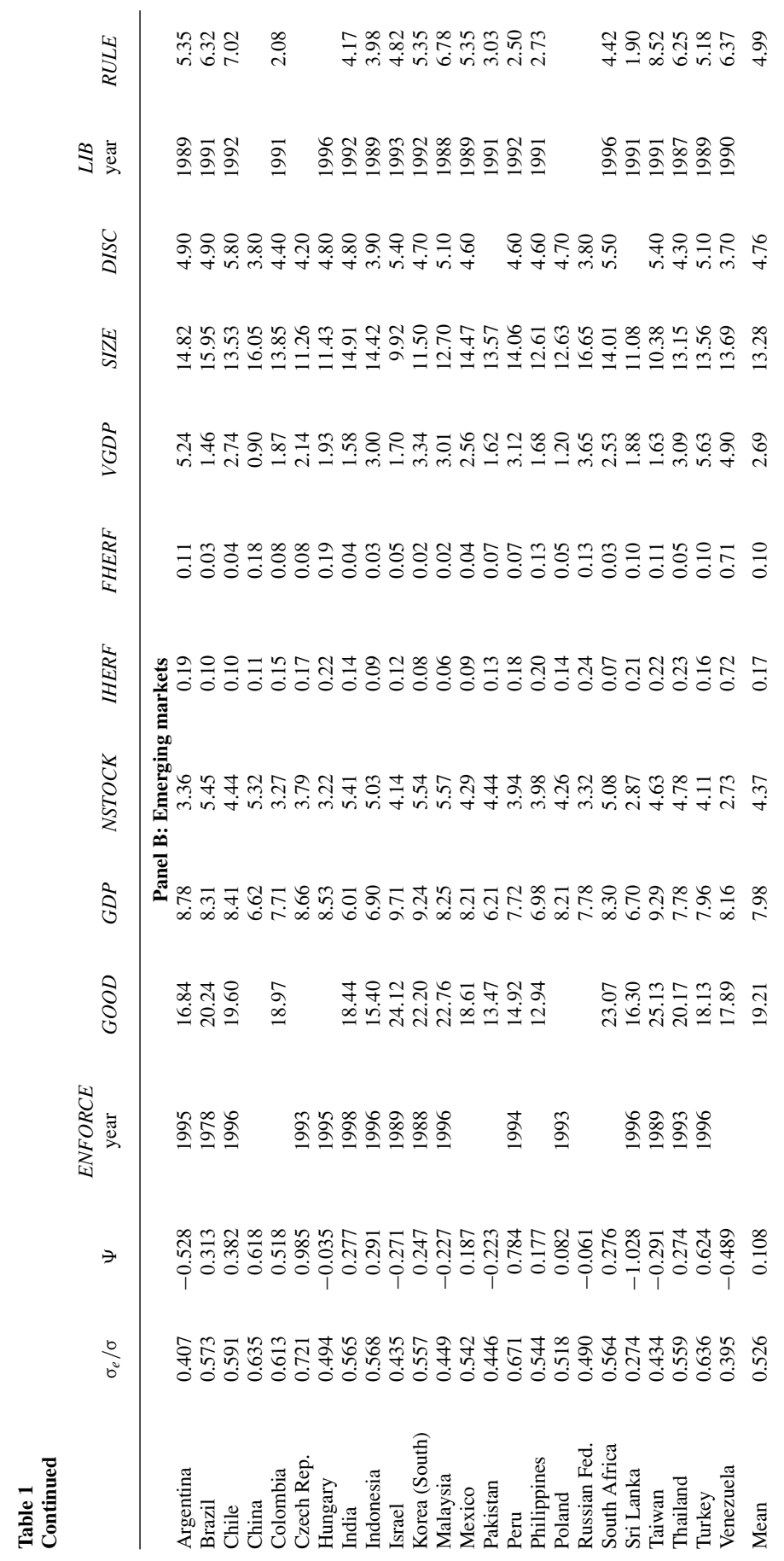




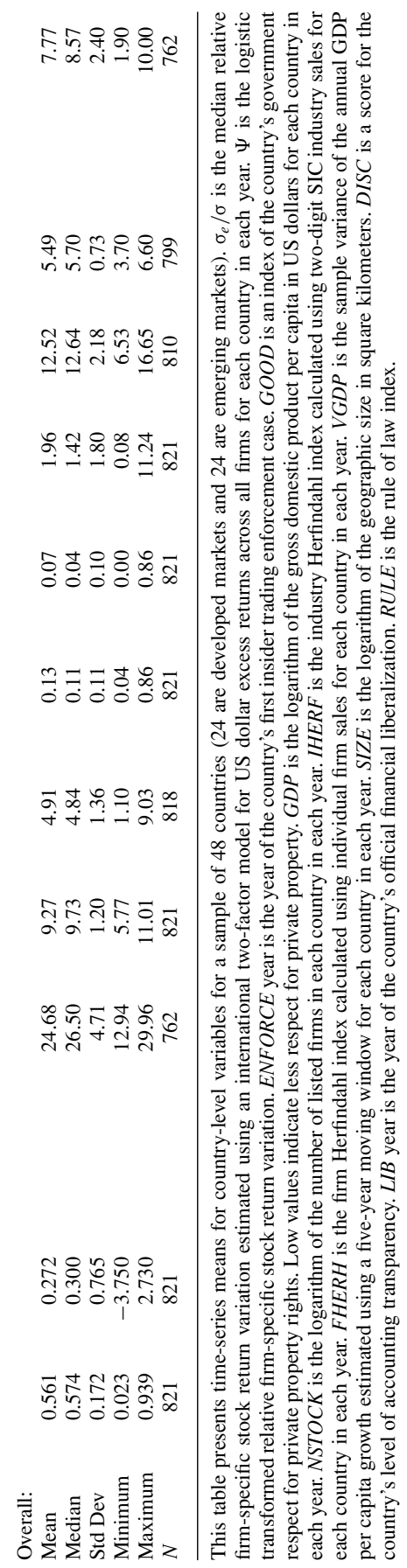




\subsection{Country-level control variables}

The focus of our country-level study is the date of a country's first enforcement of insider trading laws. We construct a dummy variable, ENFORCE, that takes the value one in the year of the country's first insider trading enforcement case and thereafter, and zero otherwise. The source of the first enforcement dates is Bhattacharya and Daouk (2002), and the years are reported in Table 1. Insider trading laws have been enforced for 35 countries in our sample (19 developed markets and 16 emerging markets). This represents $72.9 \%$ of the countries in the sample ( $76.2 \%$ in terms of country-year observations). ${ }^{3}$

We use several country-level variables as controls in the firm-specific return variation regressions. Following Morck, Yeung, and Yu (2000), to capture the extent to which a country's government respects private property rights, we construct a good government index (GOOD) as the sum of three indexes from La Porta et al. (1998), each ranging from 0 to 10. These indexes measure (1) government corruption, (2) the risk of the government's expropriation of private property, and (3) the risk that the government will repudiate contracts. Low values for each index indicate less respect for private property.

We include other country-level variables that are applied in Morck, Yeung, and Yu (2000). The first is the logarithm of a country's gross domestic product per capita in US dollars to proxy for the level of economic development $(G D P)$. Our source is the World Bank WDI database. The other variables are: number of stocks, given by the logarithm of the number of listed firms in each country $(N S T O C K)$; the industry-level Herfindahl index (IHERF) as a measure of industrial concentration, calculated using two-digit SIC industry sales for each country in each year; the firm-level Herfindahl index (FHERF) as a proxy for degree of firm concentration, calculated using firm sales for each country in each year; the volatility of economic growth as measured by the sample variance of the annual GDP per capita growth using a five-year moving window $(V G D P)$; and country size measured by the logarithm of its geographic size in square kilometers (SIZE).

The disclosure score (DISC) proxies for the country-level accounting transparency, as suggested in Jin and Myers (2006). They find that low levels of corporate disclosure (high opaqueness) are associated with low firm-specific return variation. The source of the disclosure score is the World Economic Forum Global Competitiveness Reports $(G C R)$ for the years 1999 and 2000.

We also consider the official stock market liberalization date as an additional country-level control. The source of the liberalization dates is Bekaert, Harvey, and Lundblad (2005). Use of the liberalization dummy variable as a control in the firm-specific return variation regression is motivated by the work of $\mathrm{Li}$ et al.

\footnotetext{
Bhattacharya and Daouk (2005) show that the cost of equity actually rises when a country introduces an insider trading law but does not enforce it, particularly in emerging markets. In developed markets, the mere enactment of an insider trading law seems to be effective in deterring insider activities (Ackerman and Maug, 2006). Results (not tabulated here) using the introduction of insider trading laws confirm our finding of an improvement in stock price informativeness in developed markets.
} 
(2004) ( $L I B$ equals one in the year of the liberalization and thereafter, and zero otherwise). Li et al. (2004) find that firm-specific return variation in a country increases with its openness to foreign equity investment.

Additional country-level control variables are used in some tests. RULE is the rule-of-law index, which is an assessment of the efficiency of a legal system. This index is produced by the rating agency International Country Risk, and ranges from 0 to 10 , with lower scores for countries that rank lower in the quality of the legal enforcement of rights.

To control and test for the effects of analyst activity, we use data from the historical IBES database for 1987-2003. As in Bushman, Piotroski, and Smith (2005), we calculate the number of analysts covering a firm in each year of our sample assuming that any firm not included in IBES in a given year has no analyst coverage in that year. The country-level measure of analyst coverage is the logarithm of one plus the median number of analysts across firms in each country-year (ANA).

Table 1 reports summary statistics of the control variables by country.

\section{Relation Between Enforcement and Firm-Specific Stock Return Variation}

We test whether the enforcement of insider trading laws improves stock price informativeness. First, we present panel regression evidence on the relation between enforcement and firm-specific stock return variation. Then we investigate the role of country infrastructure in explaining the relation between enforcement and firm-specific return variation. Finally, we present event-study evidence on the relation between enforcement and firm-specific return variation.

\subsection{Panel regression results}

We investigate whether enforcement of insider trading laws is associated with significant changes in the information environment, as measured by the firmspecific stock return variation. To control for other factors besides enforcement that are also likely to be related to the cross-section of firm-specific return variation, we estimate the annual time-series cross-sectional regression equation:

$$
\begin{aligned}
\Psi_{i, t}= & b_{0}+b_{1} \text { ENFORCE }_{i, t}+b_{11} \text { EMERGE }_{i, t} \\
& +b_{12} \text { ENFORCE }_{i, t} \times \text { EMERGE }_{i, t}+b_{2} \text { GOOD }_{i, t}+b_{3} \text { GDP }_{i, t} \\
& +b_{4} \text { NSTOCK }_{i, t}+b_{5} \text { IHERF }_{i, t}+b_{6} \text { FHERF }_{i, t}+b_{7} \text { VGDP }_{i, t} \\
& +b_{8} \text { SIZE }_{i, t}+b_{9} \text { DISC }_{i, t}+b_{10} \text { LIB }_{i, t}+\epsilon_{i, t},
\end{aligned}
$$

where $\Psi_{i, t}$ is the logistic transformed relative firm-specific return variation of country $i$ in year $t$. ENFORCE is a dummy variable that takes the value of one in the year of the country's first insider trading enforcement case and thereafter, and zero otherwise; $E M E R G E$ is an emerging market dummy variable; $G O O D$ is the good government index; GDP is the logarithm of a country's GDP per capita in US dollars in a given year; NSTOCK is the logarithm of the number of 
listed firms in each country in a given year; IHERF is the industry Herfindahl index; FHERF is the firm Herfindahl index; VGDP is the variance of the annual $G D P$ per capita growth; $S I Z E$ is the logarithm of its geographic size in square kilometers; DISC is the country disclosure score; and $L I B$ is a liberalization dummy.

The research on the relation of enforcement and the information environment (measured by analyst coverage) finds different results in developed markets and emerging markets. Bushman, Piotroski, and Smith (2005) find increased analyst activities following the enforcement of insider trading laws, but this increase is concentrated in emerging markets. To test for a differential response to insider trading laws enforcement across developed and emerging markets, we include an interaction variable $(E N F O R C E \times E M E R G E)$, which equals one for an emerging market that enforces insider trading laws in a given year and thereafter, and zero otherwise.

Table 2 reports the coefficient estimates for the sample of all countries. To examine the relation between the firm-specific return variation and enforcement, we estimate variants of our basic regression Equation (8). The first column is estimated by ordinary least squares (OLS), pooling all observations, and imposing the restriction $b_{12}=0$ (i.e., there is a common effect in developed and emerging markets). The ENFORCE dummy coefficient is 0.3370 with a $t$-statistic of 6.21. This result suggests that countries that enforce insider trading laws have significantly higher levels of stock price informativeness. By improving the information environment, namely, restricting insider trading, there is reduced information asymmetry between market participants, and overall participation and information collection in the stock market increases.

Column (2) of Table 2 reports estimates of Equation (8) by OLS but allows for a differential reaction in developed and emerging markets. In this estimation, the coefficient on ENFORCE $\left(b_{1}\right)$ represents the change in firm-specific stock return variation associated with the initial enforcement of insider trading laws in developed markets; the coefficient on $E N F O R C E$ plus the interaction coefficient on ENFORCE $\times$ EMERGE is the change in emerging markets $\left(b_{1}+b_{12}\right)$. The interaction coefficient $\left(b_{12}\right)$ thus measures the differential responses of emerging markets and developed markets.

The estimates indicate that firm-specific return variation is significantly more sensitive to enforcement in developed markets, as shown by the ENFORCE coefficient in column (2) of Table 2. The ENFORCE coefficient is 0.5224 with a $t$-statistic of 7.77. Enforcement in emerging markets is less influential than in developed markets, as reflected by the negative and significant coefficient on the interaction variable, ENFORCE $\times E M E R G E$, which is -0.4957 with a $t$-statistic of -4.54 . Overall, enforcement has an insignificant effect on the emerging markets' firm-specific return variation $\left(b_{1}+b_{12}\right)$.

Prior research has linked firm-specific return variation to country factors. Therefore, columns (3)-(6) of Table 2 report estimates of the basic equation using alternatively country fixed and random effects. The inclusion of country 


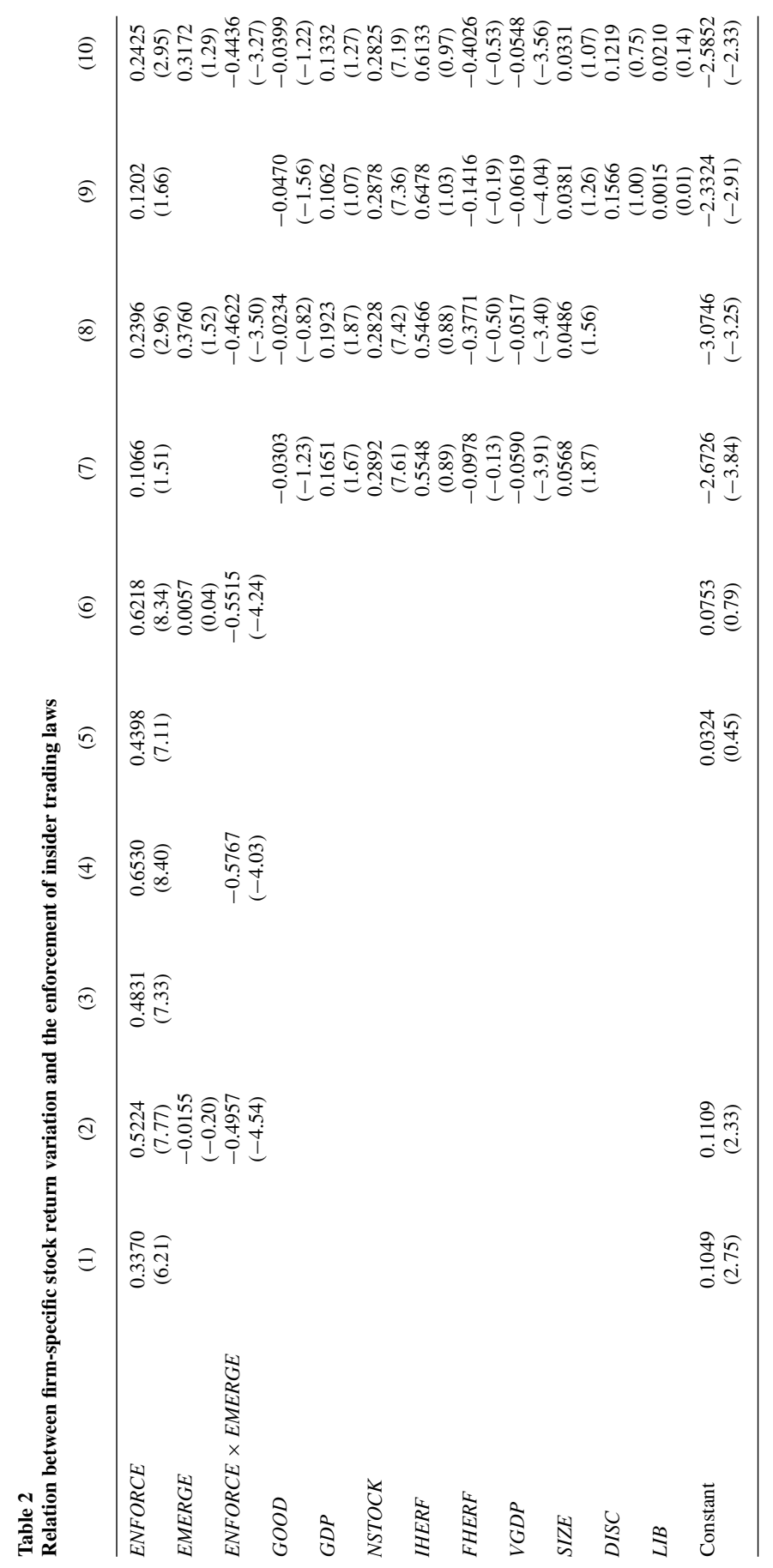




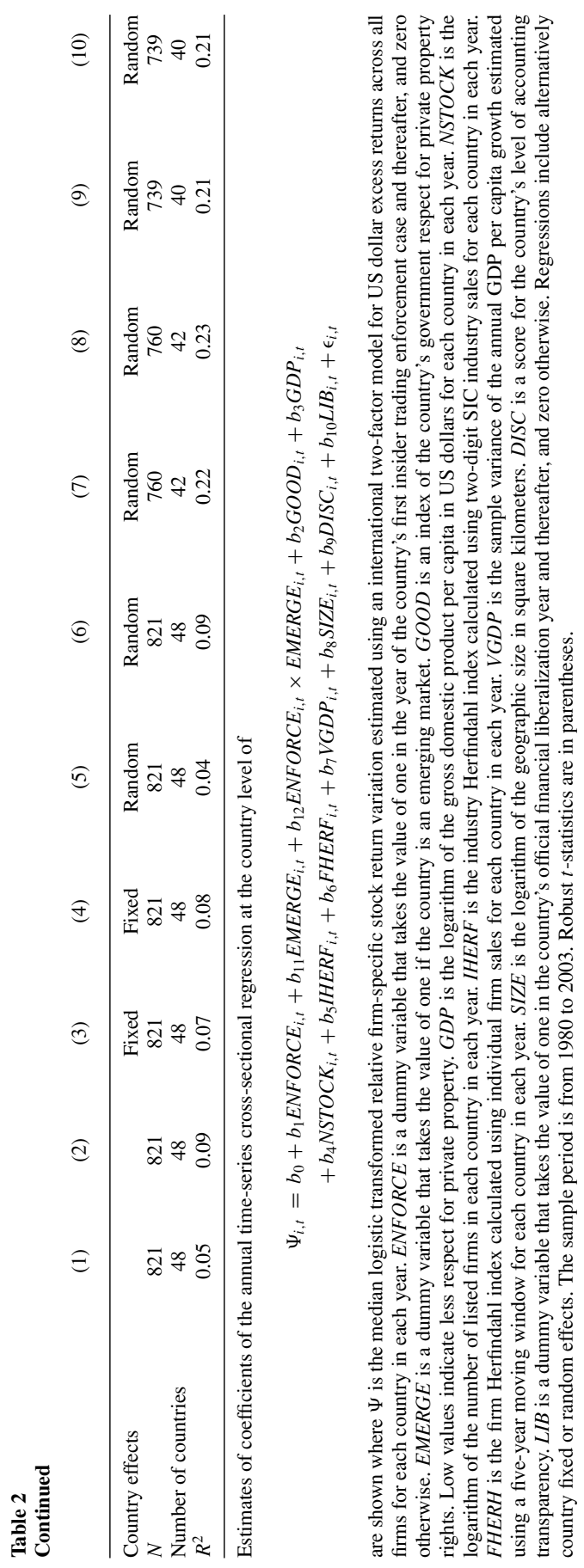


fixed or random effects should control for country-level differences, both in firm-specific return variation and in the control variables. Inclusion of country effects has no significant impact on the economic and statistical significance of the relation between firm-specific return variation and enforcement. The consistent result is a significant and positive relation between enforcement and firm-specific return variation in developed markets and an insignificant relation in emerging markets.

Finally, we also consider country-level variables that explain the crosscountry variation in firm-specific return variation as described earlier. Columns (7)-(10) of Table 2 estimate Equation (8) using random effects and countrylevel variables that are known to be correlated with the firm-specific return variation.

The results confirm a positive relation between firm-specific return variation and enforcement in developed markets and an asymmetric sensitivity in emerging markets. The ENFORCE coefficient estimates range from 0.2396 to 0.2425 when we include the interaction variable $(E N F O R C E \times E M E R G E)$, both are strongly significant. The interaction between enforcement and emerging markets remains negative and strongly significant; ranging from -0.4436 to -0.4622 , both are strongly significant.

With respect to the country-level variables, only the number of stocks and the volatility of GDP growth are statistically significant. Interestingly, contrary to prior research results (e.g., Morck, Yeung, and Yu, 2000), firm-specific return variation is insignificantly associated with the good government index and financial liberalization, once we control for the enforcement of insider trading laws.

We also estimate separate regressions for the sample of developed and emerging markets. This allows us to isolate the effect of enforcement in developed and emerging market samples. Furthermore, by estimating the model separately for the two samples of countries, we allow the coefficients on all control variables to be different across samples.

Table 3 reports the results of the separate regressions. Panel A reports estimates for developed markets, and panel B reports estimates for emerging markets. The evidence in Table 3 reinforces our primary findings in Table 2. That is, the coefficient on ENFORCE in developed markets is positive and significant, while it is insignificant in emerging markets.

Overall, the separate regression results confirm that a country's enforcement of insider trading laws improves the information environment, but the effect is concentrated in developed markets. Enforcement of insider trading laws in emerging markets does not impact the level of firm-specific information incorporated into stock prices.

\subsection{The role of infrastructure}

Why do developed markets experience an improvement in stock price informativeness after insider trading law enforcement, but the reverse happens for 
Table 3

Separate estimations for developed and emerging markets

(1)

(2)

(3)

(4)

(5)

\begin{tabular}{|c|c|c|c|c|c|}
\hline \multicolumn{6}{|c|}{ Panel A: Developed markets } \\
\hline ENFORCE & $\begin{array}{c}0.5224 \\
(8.06)\end{array}$ & $\begin{array}{c}0.6530 \\
(8.78)\end{array}$ & $\begin{array}{c}0.6216 \\
(8.71)\end{array}$ & $\begin{array}{c}0.1611 \\
(1.95)\end{array}$ & $\begin{array}{c}0.1599 \\
(1.92)\end{array}$ \\
\hline$G O O D$ & & & & $\begin{array}{c}0.0167 \\
(0.39)\end{array}$ & $\begin{array}{c}0.0032 \\
(0.06)\end{array}$ \\
\hline$G D P$ & & & & $\begin{array}{l}0.5297 \\
(2.70)\end{array}$ & $\begin{array}{l}0.5447 \\
(2.72)\end{array}$ \\
\hline NSTOCK & & & & $\begin{array}{l}0.3029 \\
(5.63)\end{array}$ & $\begin{array}{l}0.2990 \\
(5.48)\end{array}$ \\
\hline IHERF & & & & $\begin{array}{l}0.9561 \\
(1.14)\end{array}$ & $\begin{array}{l}1.0099 \\
(1.19)\end{array}$ \\
\hline FHERF & & & & $\begin{array}{l}1.7077 \\
(1.02)\end{array}$ & $\begin{array}{l}1.7037 \\
(1.01)\end{array}$ \\
\hline$V G D P$ & & & & $\begin{array}{l}-0.051 \\
(-1.93)\end{array}$ & $\begin{array}{c}-0.0522 \\
(-1.96)\end{array}$ \\
\hline SIZE & & & & $\begin{array}{c}0.0287 \\
(0.92)\end{array}$ & $\begin{array}{c}0.0263 \\
(0.83)\end{array}$ \\
\hline DISC & & & & & $\begin{array}{c}0.0841 \\
(0.37)\end{array}$ \\
\hline$L I B$ & & & & & $\begin{array}{l}-0.0498 \\
(-0.14)\end{array}$ \\
\hline Constant & $\begin{array}{c}0.1109 \\
(2.42)\end{array}$ & & $\begin{array}{c}0.0753 \\
(0.83)\end{array}$ & $\begin{array}{c}-7.5230 \\
(-4.66)\end{array}$ & $\begin{array}{l}-7.7022 \\
(-4.38)\end{array}$ \\
\hline Country effects & & Fixed & Random & Random & Random \\
\hline$N$ & 509 & 509 & 509 & 498 & 498 \\
\hline Number of countries & 24 & 24 & 24 & 23 & 23 \\
\hline$R^{2}$ & 0.11 & 0.14 & 0.11 & 0.30 & 0.30 \\
\hline \multicolumn{6}{|c|}{ Panel B: Emerging markets } \\
\hline ENFORCE & $\begin{array}{c}0.0268 \\
(0.29)\end{array}$ & $\begin{array}{c}0.0763 \\
(0.59)\end{array}$ & $\begin{array}{c}0.0699 \\
(0.62)\end{array}$ & $\begin{array}{c}-0.0998 \\
(-0.71)\end{array}$ & $\begin{array}{c}-0.0418 \\
(-0.28)\end{array}$ \\
\hline$G O O D$ & & & & $\begin{array}{l}-0.0204 \\
(-0.45)\end{array}$ & $\begin{array}{l}-0.0463 \\
(-0.94)\end{array}$ \\
\hline$G D P$ & & & & $\begin{array}{c}0.0747 \\
(0.52)\end{array}$ & $\begin{array}{l}-0.0745 \\
(-0.48)\end{array}$ \\
\hline NSTOCK & & & & $\begin{array}{c}0.1920 \\
(3.00)\end{array}$ & $\begin{array}{c}0.1625 \\
(2.19)\end{array}$ \\
\hline IHERF & & & & $\begin{array}{c}-0.1134 \\
(-0.11)\end{array}$ & $\begin{array}{c}-0.22 \\
(-0.21)\end{array}$ \\
\hline FHERF & & & & $\begin{array}{c}-0.3732 \\
(-0.34)\end{array}$ & $\begin{array}{l}-0.3545 \\
(-0.31)\end{array}$ \\
\hline$V G D P$ & & & & $\begin{array}{c}-0.0484 \\
(-2.41)\end{array}$ & $\begin{array}{l}-0.0489 \\
(-2.38)\end{array}$ \\
\hline SIZE & & & & $\begin{array}{c}0.1115 \\
(1.41)\end{array}$ & $\begin{array}{c}0.0078 \\
(0.09)\end{array}$ \\
\hline DISC & & & & & $\begin{array}{l}0.0607 \\
(0.23)\end{array}$ \\
\hline$L I B$ & & & & & $\begin{array}{c}0.1486 \\
(0.75)\end{array}$ \\
\hline Constant & $\begin{array}{c}0.0954 \\
(1.51)\end{array}$ & & $\begin{array}{c}0.0810 \\
(0.73)\end{array}$ & $\begin{array}{l}-2.2191 \\
(-1.38)\end{array}$ & $\begin{array}{c}0.6278 \\
(0.28)\end{array}$ \\
\hline
\end{tabular}


Table 3

Continued

(1)

(2)

(3)

$\begin{array}{cc}\text { Panel B: Emerging markets } \\ \text { Fixed } & \text { Random } \\ 312 & 312 \\ 24 & 24 \\ 0.00 & 0.00\end{array}$

(4)

(5)

$\begin{array}{cc}\text { Random } & \text { Random } \\ 262 & 241 \\ 19 & 17 \\ 0.16 & 0.15\end{array}$

Country effects

N 312

Number of countries

$R^{2}$

Estimates of coefficients of the annual time-series cross-sectional regression at the country level of

$$
\begin{aligned}
\Psi_{i, t}= & b_{0}+b_{1} \text { ENFORCE }_{i, t}+b_{2} \text { GOOD }_{i, t}+b_{3} \text { GDP }_{i, t}+b_{4} \text { NSTOCK }_{i, t}+b_{5} \text { IHERF }_{i, t} \\
& +b_{6} \text { FHERF }_{i, t}+b_{7} \operatorname{VGDP}_{i, t}+b_{8} \operatorname{SIZE}_{i, t}+b_{9} \text { DISC }_{i, t}+b_{10} L_{i, t}+\epsilon_{i, t}
\end{aligned}
$$

are shown where $\Psi$ is the median logistic transformed relative firm-specific stock return variation estimated using an international two-factor model for US dollar excess returns across all firms for each country in each year. Panel A uses a sample of developed markets. Panel B uses a sample of emerging markets. ENFORCE is a dummy variable that takes the value of one in the year of the country's first insider trading enforcement case and thereafter, and zero otherwise. GOOD is an index of the country's government respect for private property rights. Low values indicate less respect for private property. GDP is the logarithm of the gross domestic product per capita in US dollars for each country in each year. NSTOCK is the logarithm of the number of listed firms in each country in each year. IHERF is the industry Herfindahl index calculated using two-digit SIC industry sales for each country in each year. FHERH is the firm Herfindahl index calculated using individual firm sales for each country in each year. VGDP is the sample variance of the annual GDP per capita growth estimated using a five-year moving window for each country in each year. SIZE is the logarithm of the geographic size in square kilometers. DISC is a score for the country's level of accounting transparency. LIB is a dummy variable that takes the value of one in the country's official financial liberalization year and thereafter, and zero otherwise. Regressions include alternatively country fixed or random effects. The sample period is from 1980 to 2003 . Robust $t$-statistics are in parentheses.

emerging markets? To examine this result and to explain the asymmetry, we investigate how firm-specific stock return variation reacts to the enforcement of insider trading laws according to the quality of a country's infrastructure. The extent to which a country's government respects private property rights is measured by GOOD; the quality of its financial reporting is measured by DISC; and the efficiency of the judicial system is measured by $R U L E$, where scores are lower for countries that rank lower in the quality of legal enforcement of rights.

Table 4 reports on the estimates of the annual time-series cross-sectional regression equation:

$$
\begin{aligned}
\Psi_{i, t}= & b_{0}+b_{1} \text { ENFORCE }_{i, t}+b_{2} I N F_{i, t}+b_{12} \text { ENFORCE }_{i, t} \times I N F_{i, t} \\
& +b_{3} \text { GDP }_{i, t}+b_{4} \operatorname{NSTOCK}_{i, t}+b_{5} \operatorname{IHERF}_{i, t}+b_{6} \text { FHERF }_{i, t} \\
& +b_{7} \operatorname{VGDP}_{i, t}+b_{8} \operatorname{SIZE}_{i, t}+\epsilon_{i, t},
\end{aligned}
$$

where $I N F$ is alternatively $G O O D, D I S C$, and $R U L E$, which we use as proxies for the quality of a country's infrastructure or institutions. The interaction coefficient $b_{12}$ tests whether the impact of enforcement of insider trading laws on stock price informativeness varies depending on the quality of a country's infrastructure.

The evidence in Table 4 shows that the enforcement of insider trading laws has a more pronounced effect in countries with strong infrastructure, as 
Table 4

The role of infrastructure

(1)

(2)

\begin{tabular}{|c|c|c|c|}
\hline ENFORCE & $\begin{array}{c}-0.7299 \\
(-2.20)\end{array}$ & $\begin{array}{l}-1.2600 \\
(-2.43)\end{array}$ & $\begin{array}{l}-0.5209 \\
(-2.28)\end{array}$ \\
\hline$G O O D$ & $\begin{array}{l}-0.0466 \\
(-1.82)\end{array}$ & & \\
\hline$E N F O R C E \times G O O D$ & $\begin{array}{c}0.0337 \\
(2.58)\end{array}$ & & \\
\hline DISC & & $\begin{array}{l}-0.2439 \\
(-1.94)\end{array}$ & \\
\hline$E N F O R C E \times D I S C$ & & $\begin{array}{c}0.2526 \\
(2.72)\end{array}$ & \\
\hline$R U L E$ & & & $\begin{array}{l}-0.0935 \\
(-2.05)\end{array}$ \\
\hline$E N F O R C E \times R U L E$ & & & $\begin{array}{c}0.0785 \\
(2.88)\end{array}$ \\
\hline$G D P$ & $\begin{array}{c}0.1711 \\
(1.72)\end{array}$ & $\begin{array}{c}0.0661 \\
(0.84)\end{array}$ & $\begin{array}{c}0.1673 \\
(1.80)\end{array}$ \\
\hline NSTOCK & $\begin{array}{l}0.2807 \\
(7.35)\end{array}$ & $\begin{array}{l}0.2692 \\
(7.19)\end{array}$ & $\begin{array}{l}0.2819 \\
(7.44)\end{array}$ \\
\hline IHERF & $\begin{array}{c}0.4184 \\
(0.67)\end{array}$ & $\begin{array}{c}0.3036 \\
(0.55)\end{array}$ & $\begin{array}{c}0.4202 \\
(0.67)\end{array}$ \\
\hline FHERF & $\begin{array}{l}-0.1879 \\
(-0.25)\end{array}$ & $\begin{array}{c}-0.3641 \\
(-0.59)\end{array}$ & $\begin{array}{l}-0.0539 \\
(-0.07)\end{array}$ \\
\hline$V G D P$ & $\begin{array}{l}-0.0543 \\
(-3.58)\end{array}$ & $\begin{array}{l}-0.0544 \\
(-3.63)\end{array}$ & $\begin{array}{l}-0.0526 \\
(-3.48)\end{array}$ \\
\hline SIZE & $\begin{array}{c}0.0551 \\
(1.79)\end{array}$ & $\begin{array}{c}0.0329 \\
(1.09)\end{array}$ & $\begin{array}{c}0.0581 \\
(1.86)\end{array}$ \\
\hline Constant & $\begin{array}{l}-2.2540 \\
(-3.12)\end{array}$ & $\begin{array}{l}-0.7060 \\
(-0.87)\end{array}$ & $\begin{array}{l}-2.6876 \\
(-3.28)\end{array}$ \\
\hline Country effects & Random & Random & Random \\
\hline$N$ & 760 & 786 & 760 \\
\hline Number of countries & 42 & 40 & 42 \\
\hline$R^{2}$ & 0.22 & 0.19 & 0.23 \\
\hline
\end{tabular}

Estimates of coefficients of the annual time-series cross-sectional regression at the country level of

$$
\begin{aligned}
\Psi_{i, t}= & b_{0}+b_{1} \text { ENFORCE }_{i, t}+b_{2} \text { INF }_{i, t}+b_{12} \text { ENFORCE }_{i, t} \times I N F_{i, t}+b_{3} G D P_{i, t} \\
& +b_{4} \text { NSTOCK }_{i, t}+b_{5} \text { IHERF }_{i, t}+b_{6} \text { FHERF }_{i, t}+b_{7} \operatorname{VGDP}_{i, t}+b_{8} \operatorname{SIZE}_{i, t}+\epsilon_{i, t}
\end{aligned}
$$

are shown where $\Psi$ is the median logistic transformed relative firm-specific stock return variation estimated using an international two-factor model for US dollar excess returns across all firms for each country in each year. ENFORCE is a dummy variable that takes the value of one in the year of the country's first insider trading enforcement case and thereafter, and zero otherwise. INF is alternatively GOOD, DISC, and RULE. GOOD is an index of the country's government respect for private property rights. Low values indicate less respect for private property. DISC is a score for the country's level of accounting transparency. RULE is the rule of law index. GDP is the logarithm of the gross domestic product per capita in US dollars for each country in each year. NSTOCK is the logarithm of the number of listed firms in each country in each year. IHERF is the industry Herfindahl index calculated using two-digit SIC industry sales for each country in each year. FHERH is the firm Herfindahl index calculated using individual firm sales for each country in each year. $V G D P$ is the sample variance of the annual GDP per capita growth estimated using a five-year moving window for each country in each year. SIZE is the logarithm of the geographic size in square kilometers. Regressions include country random effects. The sample period is from 1980 to 2003. Robust $t$-statistics are in parentheses.

reflected by the positive and significant coefficient $\left(b_{12}\right)$ for the interaction variable, ENFORCE $\times I N F$. This finding holds for all three country-infrastructure characteristics. Together with the negative coefficient on ENFORCE, the results suggest that the enforcement of insider trading laws in countries with weak 
infrastructure does not improve stock price informativeness. In countries with a strong infrastructure, the enforcement of insider trading laws does indeed foster stock price informativeness.

These results highlight the complementary role of macro infrastructures. When good macro infrastructures are in place, namely, effective investor protection, good financial reporting, and an efficient judicial system, restricting insider trading provides enough incentives to other market participants to collect and trade on firm-level information. When a country's environment is poor, the enforcement of insider trading laws effectively deters insider trading, but it is not enough to improve the overall information environment. The important effect of insider trading on the incorporation of firm-specific information into stock prices is not overcome by other informed market participants following enforcement of insider trading laws, so there is no improvement in stock price informativeness. Other complementary policy measures must be undertaken before outside investors are willing to devote costly resources to the production of information.

\subsection{Event study: change in firm-specific stock return variation around enforcement}

While panel results establish a link between enforcement and the stock price informativeness as measured by the level of firm-specific return variation, they do not focus directly on the changes in firm-specific return variation around the enforcement event. Event study analysis is an alternative approach that lets us compare firm-specific return variation before and after enforcement for a given country.

To capture whether there has been a change in stock price informativeness around the time of enforcement of insider trading laws, we perform an event study analysis that compares the average levels of firm-specific return variation before and after the enforcement date. We specify an event window of three years before and after. Thus, the post-event dummy variable ENFORCE equals one for the three years after the country has enforced insider trading laws, and zero for the three years before. Since the event is centered on the year of the enforcement, we eliminate this year from the regressions. A long event window allows us to better capture the entire change in firm-specific return variation. As estimates of firm-specific return variation are intrinsically noisy, a long window lets us obtain more reliable measures of our dependent variable.

Insider trading laws have been enforced for 35 countries in our sample (19 developed markets and 16 emerging markets). In these 35 countries, 30 initiated enforcement actions during our sample period and 5 before the start of the sample period.

Figure 1 shows the average relative firm-specific stock return variation $\left(\sigma_{e}^{2} / \sigma^{2}\right)$ in the three-year period before and after a country's first-time enforcement of insider trading laws for all countries where the enforcement occurred 
Panel A: Developed markets

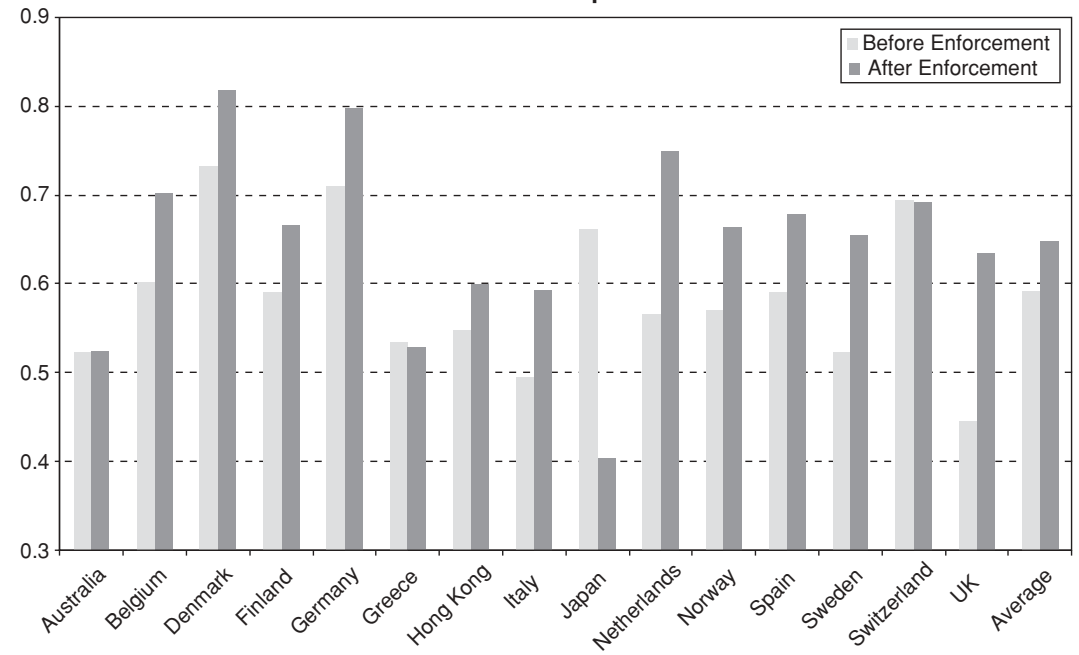

Panel B: Emerging markets

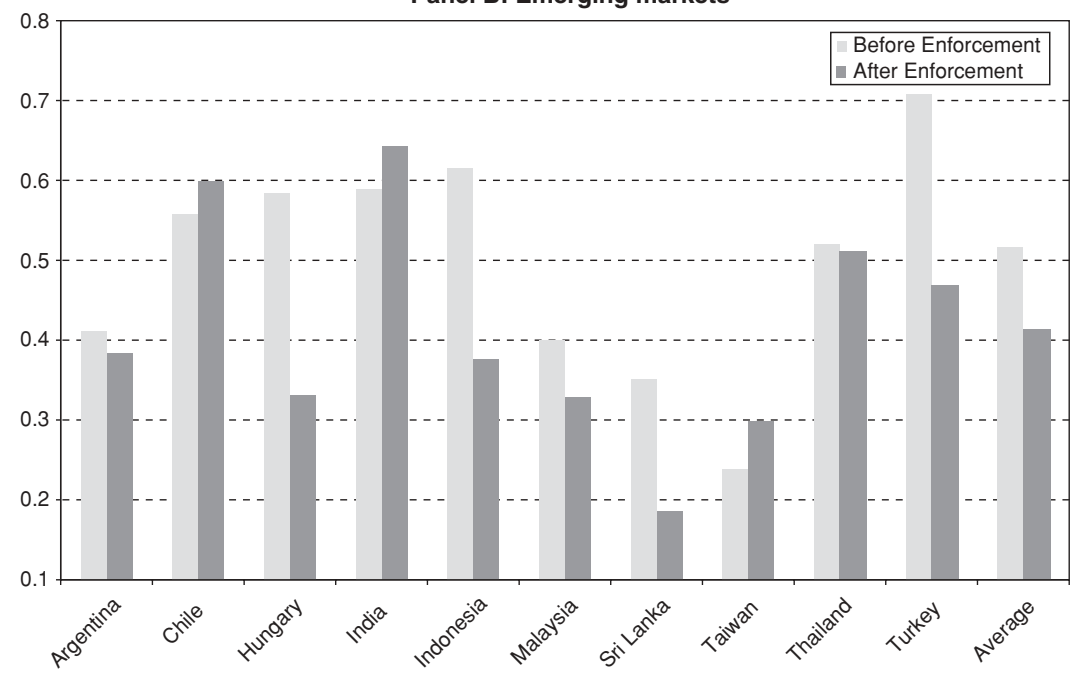

Figure 1

Firm-specific stock return variation around the enforcement of insider trading laws

Panel A plots the average relative firm-specific return variation in the period before and after the enforcement in developed markets. Panel B plots the average relative firm-specific return variation in the period before and after the enforcement in emerging markets. The event window includes the three-year period before and after the enforcement year, excluding the year of the enforcement. Firm-specific stock return variation is the median across all firms for each country in each year estimated using an international two-factor model for US dollar excess returns. 
Table 5

Change in firm-specific stock return variation around the enforcement of insider trading laws

ENFORCE
ENFORCE $\times$ EMERGE

$E N F O R C E \times G O O D$

$E N F O R C E \times D I S C$

ENFORCE $\times$ RULE
(1)

(2)

0.0020

0.2740
$(2.93)$
-0.6873
$(-4.43)$

$-0.6873$

$(-4.43)$
(3)

-1.6285
$(-4.44)$
0.0692
$(4.65)$

(4.65)

(4)

$-2.7189$

(-4.56)

$-1.0841$

(-4.41)

0.5022

(4.69)

0.1466

(4.81)

\begin{tabular}{|c|c|c|c|c|c|}
\hline Country effects & Fixed & Fixed & Fixed & Fixed & Fixed \\
\hline$N$ & 146 & 146 & 140 & 140 & 140 \\
\hline Number of events & 25 & 25 & 25 & 25 & 25 \\
\hline$R^{2}$ & 0.56 & 0.62 & 0.63 & 0.56 & 0.63 \\
\hline
\end{tabular}

Estimates of event-study regression are shown where $\Psi$ is the median logistic transformed relative firm-specific stock return variation estimated using an international two-factor model for US dollar excess returns across all firms for each country in each year. The event window includes the three-year period before and after the enforcement year, excluding the year of the enforcement. ENFORCE is a dummy variable that takes the value of one in the year of the country's first insider trading enforcement case and thereafter, and zero otherwise. EMERGE is a dummy variable that takes the value of one if the country is an emerging market. GOOD is an index of the country's government respect for private property rights. Low values indicate less respect for private property. DISC is a score for the country's level of accounting transparency. RULE is the rule of law index. Regressions include country fixed effects. The sample period is from 1980 to 2003 . Robust $t$-statistics are in parentheses.

during the sample period (1980-2003). Panel A shows the results for developed markets (15 events) and panel B for emerging markets (10 events). ${ }^{4}$

In all cases except Japan, the evidence for the developed markets is consistent with an increase in firm-specific return variation following the enforcement. ${ }^{5}$ In emerging markets, only three countries show an increase in firm-specific return variation after the initial enforcement of insider trading laws. On average, the relative firm-specific return variation increases from 0.5918 to 0.6470 in developed markets and declines from 0.5159 to 0.4125 in emerging markets.

The increase in firm-specific return variation in developed markets after the enforcement of insider trading laws could be associated with a more general trend rather than enforcement of these laws. To check for this possibility, Figure 2 shows the time series of relative firm-specific return variation around the year of the enforcement for each country. There is no clear evidence of a trend in firm-specific return variation in the majority of countries, but there are some exceptions such as Hong Kong and Switzerland (we perform additional tests that address this concern in a later robustness section).

Table 5 reports estimates of the event-study regressions using country fixed effects. Country fixed effects implicitly control for the calendar year of each

4 There are five countries (Czech Republic, Israel, Peru, Poland, and South Korea) that enforced insider trading laws during our sample period but cannot be included in the event study because there are no data available before the enforcement event.

5 The enforcement event in Japan occurred in the same year as the country's stock market crash. The post-crash period is characterized by a low level of firm-specific return variation. 

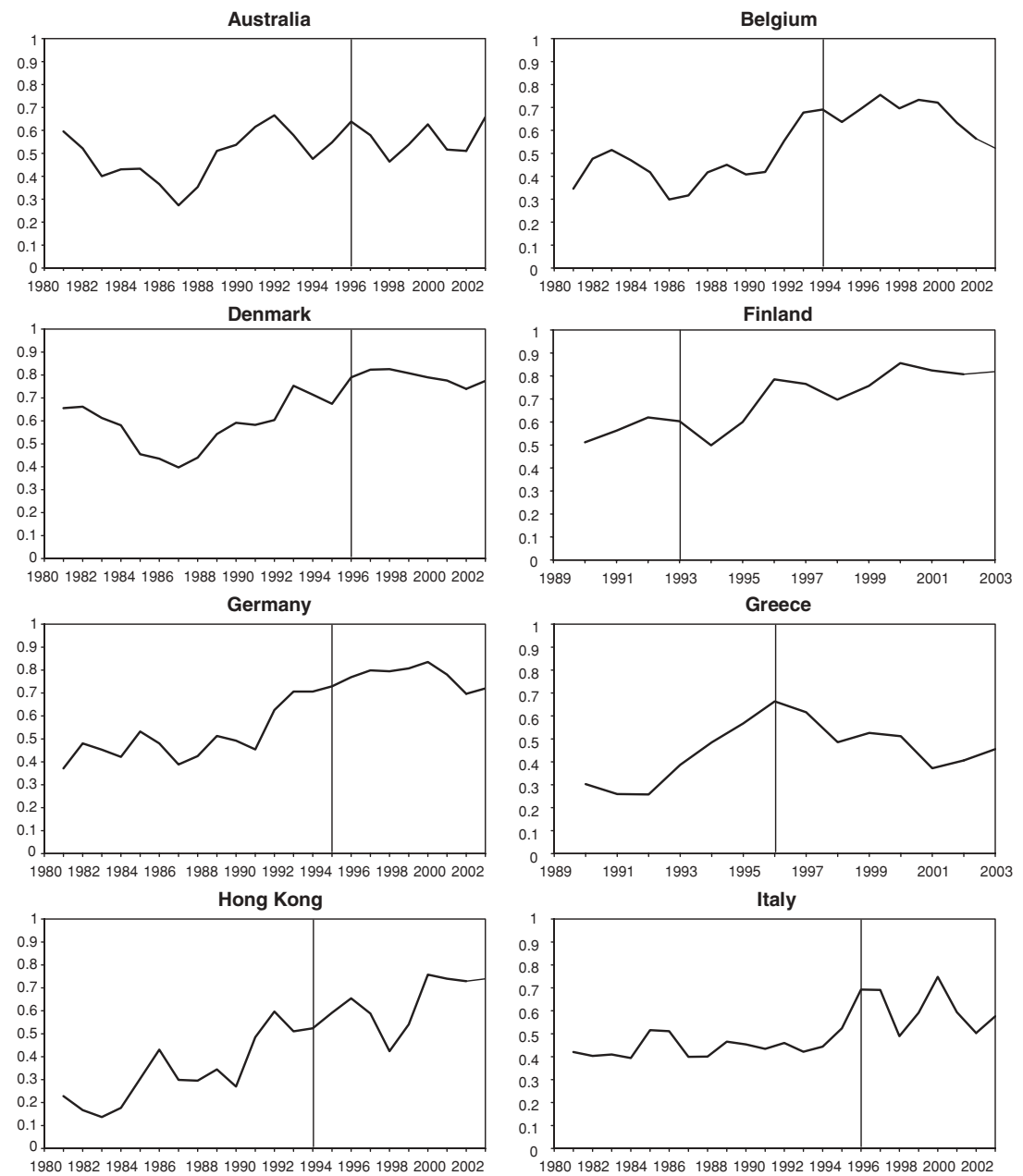

\section{Figure 2}

Firm-specific stock return variation

This figure plots the time-series of the relative firm-specific return variation in each country using a two-year backward moving average. Firm-specific stock return variation is the median across all firms for each country in each year estimated using an international two-factor model for US dollar excess returns. The year of the enforcement of insider trading laws is represented by a vertical line.

enforcement, which helps to assure that our results are not driven by a particular year. The results in column (1) show an insignificant increase in the price informativeness variable around the enforcement event for the sample of all countries. This is not surprising, given our previous evidence of an asymmetric relation of enforcement and firm-specific return variation in developed and emerging markets.

In fact, in column (2) of Table 5 when we include the ENFORCE variable and its interaction with $E M E R G E$, we find results consistent with our primary 

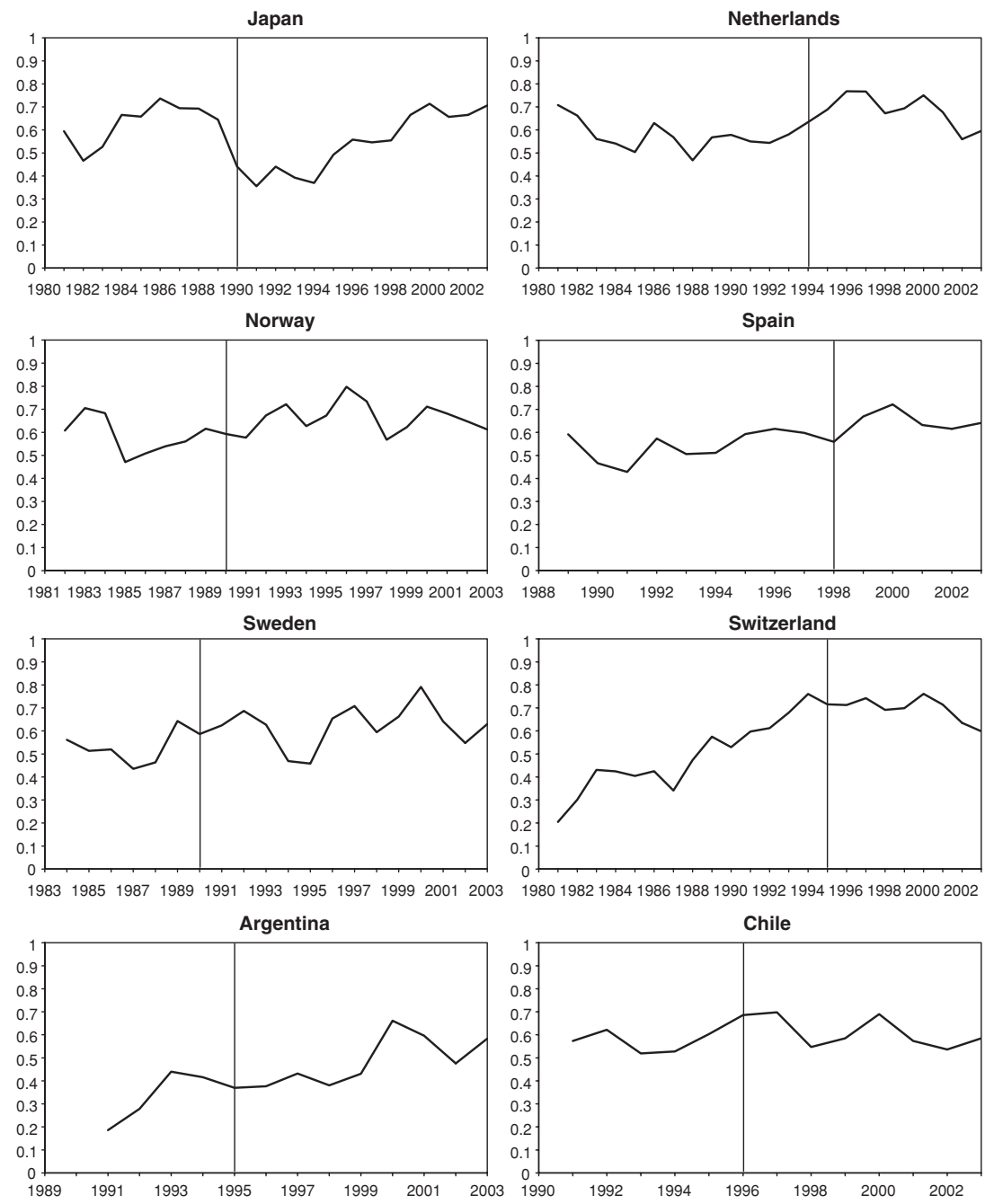

Figure 2

Continued

findings. There is improved stock price informativeness following enforcement in developed markets, as shown by the ENFORCE coefficient of 0.2740 , with a $t$-statistic of 2.93. Moreover, there is a differential reaction in emerging markets compared to developed markets to the enforcement of insider trading laws. The interaction variable coefficient is negative and strongly significant.

Columns (3)-(5) of Table 5 show similar results but using an interaction between enforcement and the quality of the country's infrastructure, as measured by GOOD, DISC, and RULE. In all cases, the results are consistent with the previous panel regression results. The effect of the enforcement of insider 

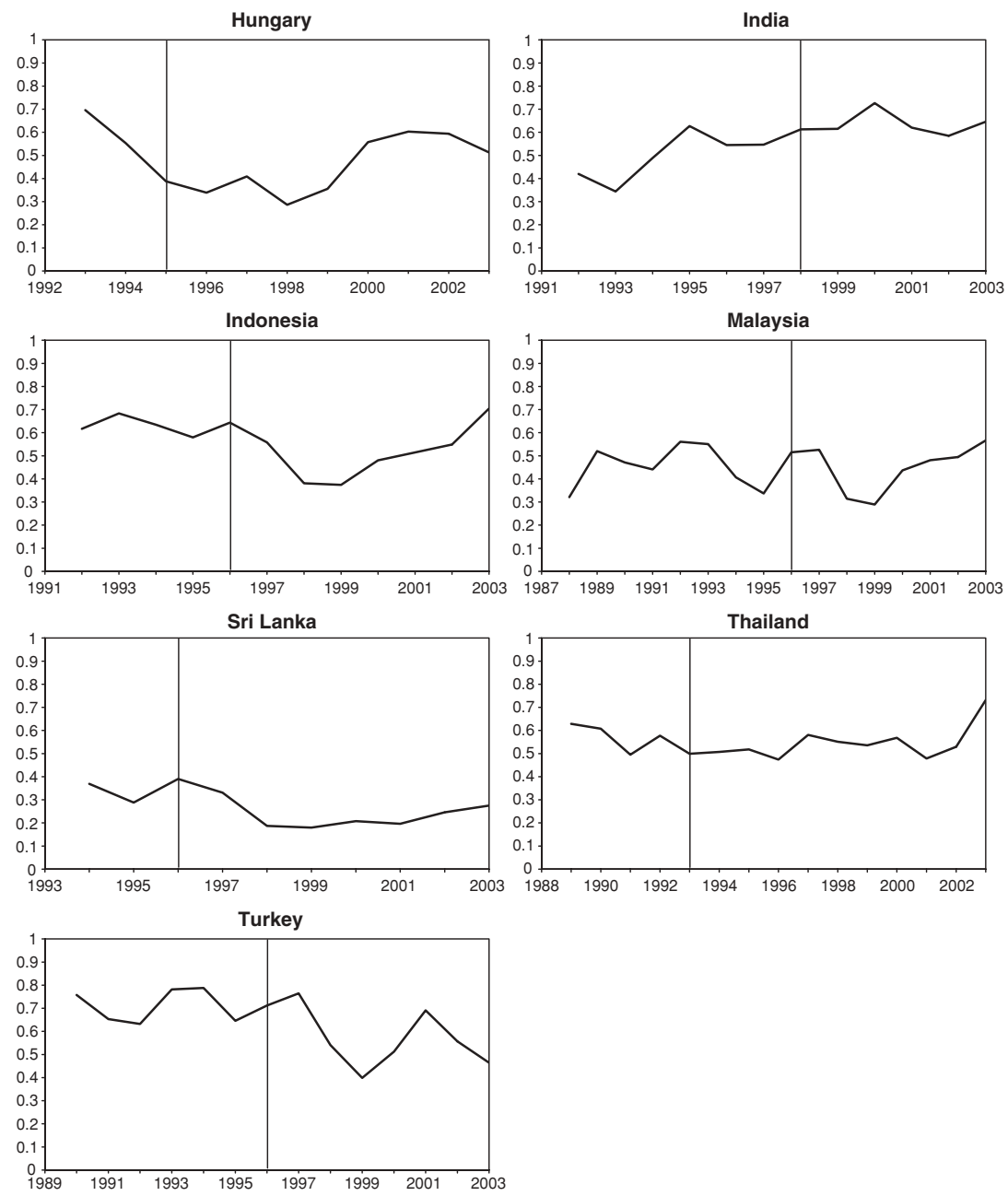

Figure 2

Continued

trading laws on stock price informativeness is concentrated in countries with strong local infrastructures.

On the one hand, insider trading laws reduce the level of insider trading. On the other hand, in some countries, insiders play a strong role in disseminating information. After enforcement of insider trading laws, insiders become less important, with less of an informational role in influencing prices.

\section{Robustness}

We perform several robustness checks of our main findings, namely, the positive relation between enforcement and firm-specific return variation in developed 
markets and the different relations in emerging markets versus developed markets. First, we address concerns about the measurement of firm-specific return variation and consider several sample and methodological variations. Next, we present evidence supporting the interpretation of firm-specific return variation as a measure of price informativeness using alternative measures. Finally, we present simulation-based results that support the informational interpretation of firm-specific return variation.

\subsection{Robustness checks}

One concern would be the measurement of firm-specific stock return variation. Our primary results so far use firm-specific return variation estimated from an international two-factor model (local and US market index return) and monthly excess returns. Our robustness checks test different models of returns, return frequencies, and samples of countries and firms.

Columns (1) and (2) of Table 6 report on the results of estimations of Equation (8) with country random effects and controls using different measures of firmspecific return variation. Column (1) estimates firm-specific return variation using weekly instead of monthly returns. ${ }^{6}$ Column (2) uses the local market model (one-factor) instead of the two-factor international model. The positive relation between enforcement and firm-specific return variation in developed markets and the insignificant (or even negative) relation in emerging markets is confirmed by these results. For example, the ENFORCE coefficient increases from 0.2396 ( $t$-statistic of 2.96) in the two-factor international model to 0.3946 $(t$-statistic of 3.95) in the local market model.

Columns (3)-(7) of Table 6 show that our results stand up to additional robustness checks. First, we reestimate Equation (8) for a restricted sample period: 1990-2003. We choose 1990 to start this restricted sample period because the country coverage of Worldscope was significantly expanded in this year. The results for the 1990-2003 sample period are reported in column (3). Column (4) excludes the years of the Asian financial crisis (1997-1998), as significantly more enforcements occurred in 1995-1996, so the period after those enforcements would include the Asian financial crisis. ${ }^{7}$ Column (5) considers a sample excluding Japan because that country experienced depressed firm-specific return variation in the 1990s following its stock market crash. Column (6) eliminates financial sector firms (SIC Codes 6000-6999) from the sample used to estimate country-level firm-specific return variation. Column (7) considers the average firm-specific return variation for each country in each year instead of the median across firms. The primary results are unaffected by

\footnotetext{
6 The use of weekly (or daily) returns can generate a nonsynchronous trading bias, especially in emerging markets. Results (not tabulated here) using the Scholes and Williams (1977) method or French, Schwert, and Stambaugh (1987) variance-covariance correction for serial and cross-serial correlation in returns confirm our primary findings.

7 We obtain similar results if we consider only 1997 or 1998 as the crisis period.
} 


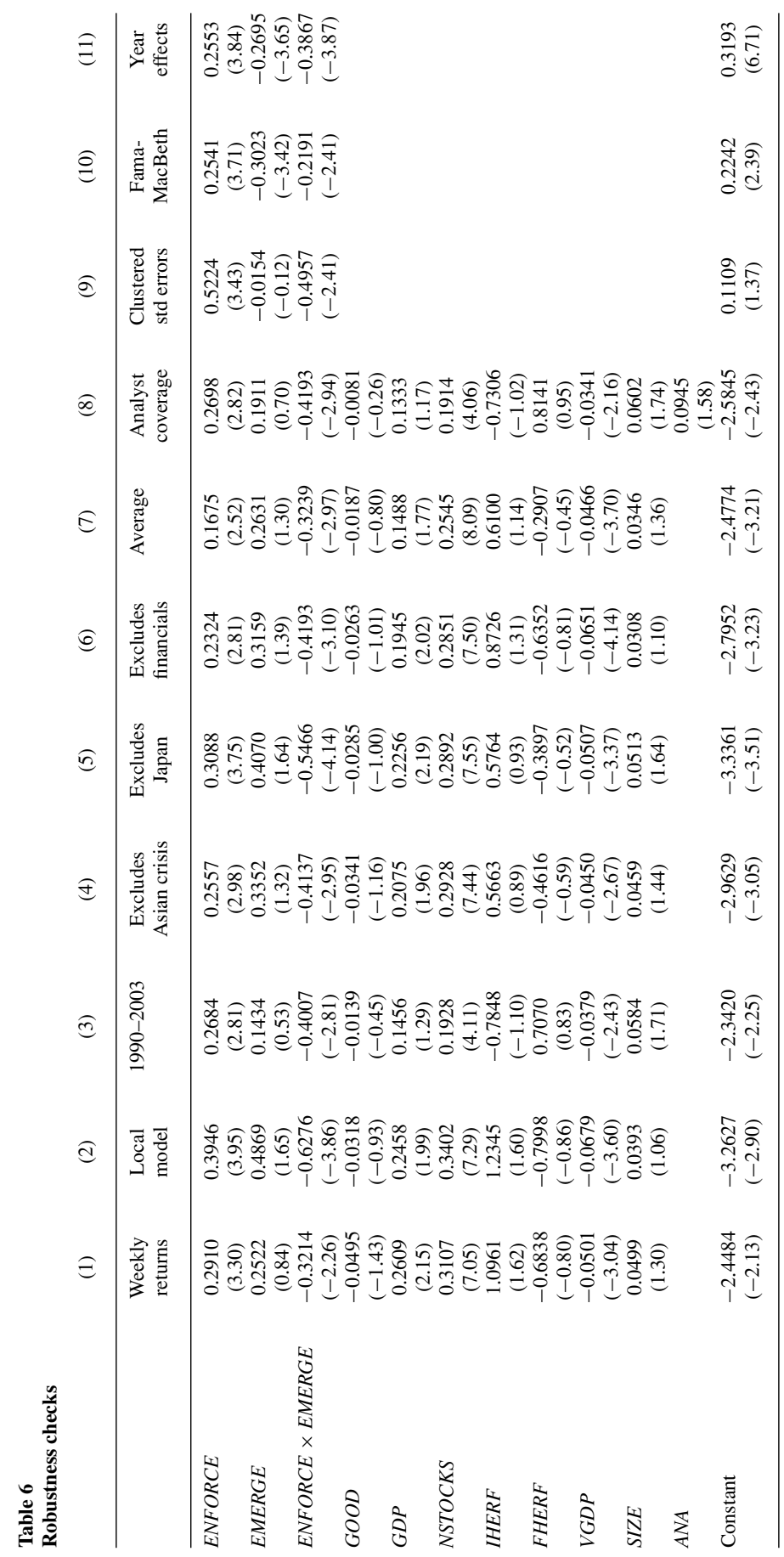




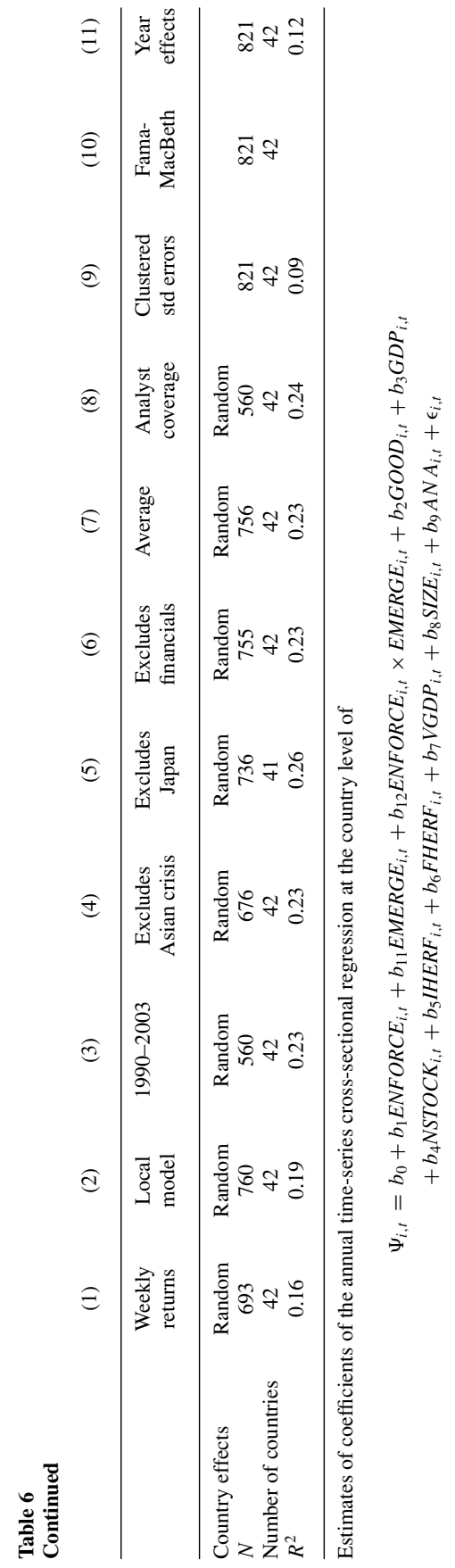

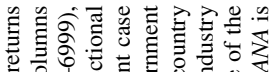
记 远

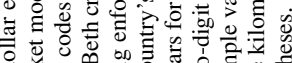

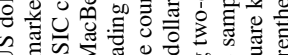

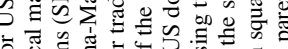

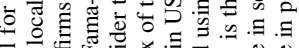

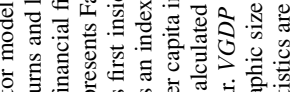

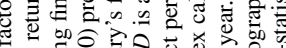

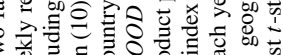

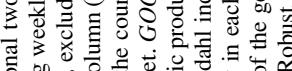
on o

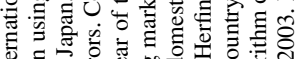

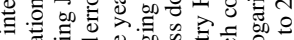

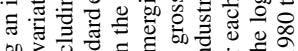

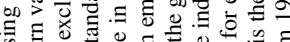

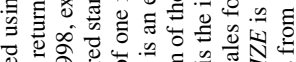

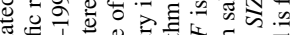

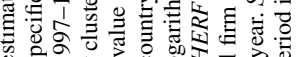
के

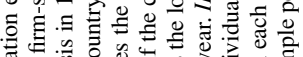

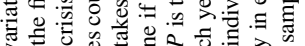

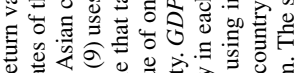

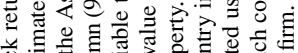

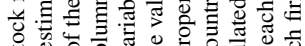
के

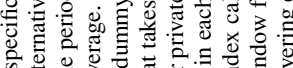

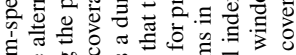

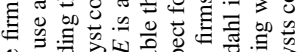

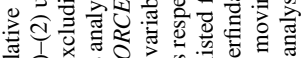

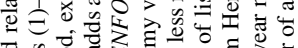

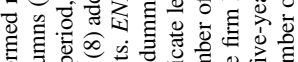

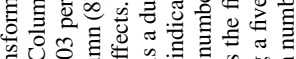

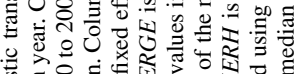

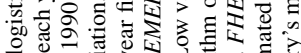

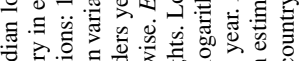

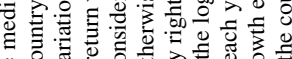

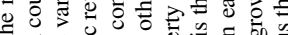

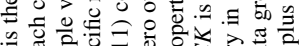

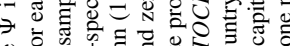

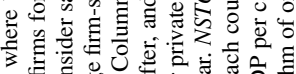

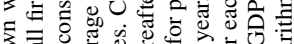

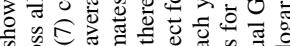

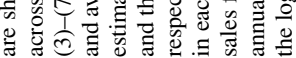


these sample variations. The ENFORCE coefficient is positive and significant, while the interaction coefficient remains negative and significant.

Column (8) of Table 6 investigates how analyst coverage impacts the relation between enforcement of insider trading laws and firm-specific return variation. Bushman, Piotroski, and Smith (2005) find increased analyst coverage in emerging markets after the initial enforcement of insider trading laws. This finding is not necessarily inconsistent with our results of no improvement in the price informativeness of emerging markets. Analysts and insiders may not be perfect substitutes in terms of their contribution to the incorporation of information into stock prices. In fact, there is evidence that analysts produce marketwide (not firm-specific) information in emerging markets (Chan and Hameed, 2006). To investigate the role of analysts, we expand Equation (8) to include analyst coverage $(A N A)$ as an additional control variable. The results controlling for analyst coverage confirm our primary findings. The estimates indicate that firm-specific return variation is significantly more sensitive to the enforcement in developed markets. Enforcement in emerging markets is less influential than in developed markets. The ANA coefficient is insignificant.

Columns (9) and (10) of Table 6 check the robustness of our estimation methodology. We use country fixed effects and random effects to adjust for within-country correlation. Column (9) uses country clustered standard errors that are a different way to take into account that errors are correlated within countries (but independent across countries); see Petersen (2007). Column (10) uses Fama-MacBeth cross-sectional estimates, which provides a way to account for cross-sectional dependence (i.e., errors are not independent across countries in a given year). Column (11) uses year fixed effects to account for cross-sectional dependence in each period and also address the concern of a general trend in the dependent variable. Primary results are not affected by these different estimators. The ENFORCE coefficient is positive and significant, while the interaction coefficient remains negative and significant.

We further check the possibility that a general trend in firm-specific variation is driving our results by using trend-adjusted data. To trend-adjust firm-specific variation, we note that five countries (Canada, France, Singapore, United States, and Brazil) enforced insider trading restrictions prior to the start of our sample period. Therefore, these countries exhibit no variation in the ENFORCE variable and should not influence the tests. We define a trend-adjusted firm-specific variation variable as the raw firm-specific variation in country $i$ in year $t\left(\Psi_{i, t}\right)$ less the average $\Psi_{i, t}$ for the five benchmark countries plus the UK in the same calendar year. ${ }^{8}$ Table 7 presents results using trend-adjusted data that confirm our primary findings.

Overall, all the evidences are consistent with the idea that the relation between a country's enforcement of insider trading laws and the information

8 We also include the UK as benchmark country, as the enforcement of insider trading laws occurred in the second year of our sample (1981). Bushman, Piotroski, and Smith (2005) use a similar adjusted procedure for analyst coverage and also include the UK in the benchmark group. Results are not affected if we do not include the UK. 
Table 7

Trend-adjusted data

(1)

(2)

(3)

(4)

(5)

\begin{tabular}{|c|c|c|c|c|c|}
\hline ENFORCE & $\begin{array}{c}0.1875 \\
(2.48)\end{array}$ & $\begin{array}{c}0.1730 \\
(2.28)\end{array}$ & $\begin{array}{c}0.1742 \\
(2.34)\end{array}$ & $\begin{array}{c}0.1333 \\
(1.99)\end{array}$ & $\begin{array}{c}0.1520 \\
(2.05)\end{array}$ \\
\hline$E M E R G E$ & $\begin{array}{l}-0.2828 \\
(-3.91)\end{array}$ & & $\begin{array}{l}-0.3034 \\
(-2.18)\end{array}$ & $\begin{array}{c}0.0486 \\
(0.19)\end{array}$ & $\begin{array}{l}-0.0999 \\
(-0.41)\end{array}$ \\
\hline$E N F O R C E \times E M E R G E$ & $\begin{array}{l}-0.2728 \\
(-2.44)\end{array}$ & $\begin{array}{l}-0.2520 \\
(-2.01)\end{array}$ & $\begin{array}{l}-0.2403 \\
(-1.99)\end{array}$ & $\begin{array}{l}-0.2394 \\
(-1.75)\end{array}$ & $\begin{array}{l}-0.2222 \\
(-1.67)\end{array}$ \\
\hline$G O O D$ & & & & $\begin{array}{c}0.0423 \\
(1.44)\end{array}$ & $\begin{array}{c}0.0134 \\
(0.41)\end{array}$ \\
\hline$G D P$ & & & & $\begin{array}{c}-0.0268 \\
(-0.25)\end{array}$ & $\begin{array}{l}-0.0990 \\
(-0.94)\end{array}$ \\
\hline NSTOCK & & & & $\begin{array}{c}0.0877 \\
(1.62)\end{array}$ & $\begin{array}{c}0.0915 \\
(1.66)\end{array}$ \\
\hline IHERF & & & & $\begin{array}{c}0.2548 \\
(0.40)\end{array}$ & $\begin{array}{l}0.2022 \\
(0.32)\end{array}$ \\
\hline FHERF & & & & $\begin{array}{l}-0.9250 \\
(-1.20)\end{array}$ & $\begin{array}{l}-0.9834 \\
(-1.30)\end{array}$ \\
\hline$V G D P$ & & & & $\begin{array}{c}-0.0368 \\
(-2.27)\end{array}$ & $\begin{array}{l}-0.0404 \\
(-2.48)\end{array}$ \\
\hline SIZE & & & & $\begin{array}{l}0.0695 \\
(1.63)\end{array}$ & $\begin{array}{c}0.0290 \\
(0.73)\end{array}$ \\
\hline DISC & & & & & $\begin{array}{c}0.1139 \\
(0.68)\end{array}$ \\
\hline$L I B$ & & & & & $\begin{array}{l}-0.2400 \\
(-1.61)\end{array}$ \\
\hline Constant & $\begin{array}{c}-0.3574 \\
(-7.95)\end{array}$ & & $\begin{array}{c}-0.3570 \\
(-3.71)\end{array}$ & $\begin{array}{c}-2.1928 \\
(-2.16)\end{array}$ & $\begin{array}{l}-1.3316 \\
(-1.24)\end{array}$ \\
\hline Country effects & & Fixed & Random & Random & Random \\
\hline$N$ & 696 & 696 & 696 & 635 & 614 \\
\hline Number of countries & 42 & 42 & 42 & 36 & 34 \\
\hline$R^{2}$ & 0.08 & 0.01 & 0.08 & 0.15 & 0.12 \\
\hline
\end{tabular}

Estimates of coefficients of the annual time-series cross-sectional regression at the country level of

$$
\begin{aligned}
\Psi_{i, t}= & b_{0}+b_{1} \text { ENFORCE }_{i, t}+b_{11} \text { EMERGE }_{i, t}+b_{12} \text { ENFORCE }_{i, t} \times \text { EMERGE }_{i, t} \\
& +b_{2} \text { GOOD }_{i, t}+b_{3} \text { GDP }_{i, t}+b_{4} \text { NSTOCK }_{i, t}+b_{5} \text { IHERF }_{i, t}+b_{6} \text { FHERF }_{i, t} \\
& +b_{7} \text { VGDP }_{i, t}+b_{8} \text { SIZE }_{i, t}+b_{9} \text { DISC }_{i, t}+b_{10} \text { LIB }_{i, t}+\epsilon_{i, t}
\end{aligned}
$$

are shown where $\Psi$ is the median logistic transformed relative firm-specific stock return variation estimated using an international two-factor model for US dollar excess returns across all firms for each country in each year. Trend-adjusted data are defined as the raw level of $\Psi_{i, t}$ less the average level of $\Psi$ in the same calendar year reported by the six countries that enforced insider trading restrictions prior to 1982. ENFORCE is a dummy variable that takes the value of one in the year of the country's first insider trading enforcement case and thereafter, and zero otherwise. EMERGE is a dummy variable that takes the value of one if the country is an emerging market. $G O O D$ is an index of the country's government respect for private property rights. Low values indicate less respect for private property. GDP is the logarithm of the gross domestic product per capita in US dollars for each country in each year. NSTOCK is the logarithm of the number of listed firms in each country in each year. IHERF is the industry Herfindahl index calculated using two-digit SIC industry sales for each country in each year. FHERH is the firm Herfindahl index calculated using individual firm sales for each country in each year. $V G D P$ is the sample variance of the annual GDP per capita growth estimated using a five-year moving window for each country in each year. SIZE is the logarithm of the geographic size in square kilometers. DISC is a score for the country's level of accounting transparency. $L I B$ is a dummy variable that takes the value of one in the country's official financial liberalization year and thereafter, and zero otherwise. Regressions include alternatively country fixed or random effects. The sample period is from 1980 to 2003. Robust $t$-statistics are in parentheses. 
environment is asymmetric, depending on the development of the country. Our key findings are not affected by constructing the dependent variable using different metrics, samples, or methodologies. Enforcement always increases firm-specific return variation in developed markets, but the result is the opposite in emerging markets.

\subsection{Alternative measures of stock price informativeness}

This informational interpretation of firm-specific return variation, however, is not without controversy. Limits to arbitrage, pricing errors, and noise also result in volatility.

Dasgupta, Gan, and Gao (2006) develop a model (derived from Jin and Myers, 2006) that suggests that the relation between price informativeness and firm-specific return variation is ambiguous. More transparency can have different impacts on firm-specific return variation, depending on the quality of legal institutions.

To substantiate our informational interpretation of the enforcement-firmspecific return variation relation, we next test for the relation between enforcement and two alternative dependent variables that measure price informativeness. The information-based trading measure suggested by Llorente et al. (2002) and the Durnev et al. (2003) measure of the extent to which stock prices incorporate information about future earnings.

Recent research provides targeted information flow indexes and some indexes of future earnings information contained in stock prices, which we investigate here.

We estimate the regression equation:

$$
\begin{aligned}
\theta_{i, t}= & b_{0}+b_{1} \text { ENFORCE }_{i, t}+b_{11} \text { EMERGE }_{i, t}+b_{12} \text { ENFORCE }_{i, t} \times \text { EMERGE }_{i, t}, \\
& +b_{2} \text { GOOD }_{i, t}+b_{3} \text { GDP }_{i, t}+b_{4} \text { NSTOCK }_{i, t}+b_{5} \text { IHERF }_{i, t}+b_{6} \text { FHERF }_{i, t} \\
& +b_{7} \operatorname{VGDP}_{i, t}+b_{8} \text { SIZE }_{i, t}+b_{9} \text { DISC }_{i, t}+b_{10} \text { LIB }_{i, t}+\epsilon_{i, t},
\end{aligned}
$$

where $\theta_{i, t}$ is the information trading measure of Llorente et al. (2002) for country $i$ (median $\theta$ across firms) in year $t$.

Table 8 reports the estimates of the regression Equation (10). The first column is estimated by OLS. Columns (2)-(5) include alternatively country fixed effects, random effects, and country-level control variables. The evidence in this table confirms that first-time enforcement of insider trading laws is positively associated with price informativeness in developed markets. The ENFORCE coefficient estimates range from 0.0358 to 0.0659 , and are always statistically significant. These results substantiate the interpretation of firm-specific return variation as a measure of stock price informativeness. The interaction between enforcement and emerging markets is always negative and significant at the $10 \%$ level when we include country fixed or random effects. The evidence confirms that price informativeness is less sensitive to enforcement in emerging 
Table 8

Alternative measures of stock price informativeness

(1) (2)

(3)

(4)

(5)

\begin{tabular}{|c|c|c|c|c|c|}
\hline ENFORCE & $\begin{array}{c}0.0358 \\
(2.62)\end{array}$ & $\begin{array}{c}0.0659 \\
(3.29)\end{array}$ & $\begin{array}{c}0.0403 \\
(2.74)\end{array}$ & $\begin{array}{c}0.0534 \\
(3.27)\end{array}$ & $\begin{array}{c}0.0538 \\
(3.20)\end{array}$ \\
\hline$E M E R G E$ & $\begin{array}{l}-0.0227 \\
(-1.57)\end{array}$ & & $\begin{array}{l}-0.0207 \\
(-1.29)\end{array}$ & $\begin{array}{l}-0.0035 \\
(-0.12)\end{array}$ & $\begin{array}{l}0.0116 \\
(-0.37)\end{array}$ \\
\hline$E N F O R C E \times E M E R G E$ & $\begin{array}{l}-0.0194 \\
(-1.01)\end{array}$ & $\begin{array}{l}-0.0625 \\
(-1.92)\end{array}$ & $\begin{array}{l}-0.0240 \\
(-1.15)\end{array}$ & $\begin{array}{l}-0.0417 \\
(-1.75)\end{array}$ & $\begin{array}{l}-0.0427 \\
(-1.71)\end{array}$ \\
\hline$G O O D$ & & & & $\begin{array}{r}0.0007 \\
(0.21)\end{array}$ & $\begin{array}{c}0.0020 \\
(0.54)\end{array}$ \\
\hline$G D P$ & & & & $\begin{array}{c}0.0050 \\
(0.39)\end{array}$ & $\begin{array}{c}0.0120 \\
(0.85)\end{array}$ \\
\hline NSTOCK & & & & $\begin{array}{c}-0.0113 \\
(-1.81)\end{array}$ & $\begin{array}{l}-0.0122 \\
(-1.87)\end{array}$ \\
\hline IHERF & & & & $\begin{array}{c}0.1784 \\
(1.39)\end{array}$ & $\begin{array}{c}0.1975 \\
(1.47)\end{array}$ \\
\hline FHERF & & & & $\begin{array}{l}-0.1765 \\
(-1.31)\end{array}$ & $\begin{array}{l}-0.2078 \\
(-1.50)\end{array}$ \\
\hline$V G D P$ & & & & $\begin{array}{c}0.0000 \\
(0.01)\end{array}$ & $\begin{array}{c}0.0004 \\
(0.13)\end{array}$ \\
\hline SIZE & & & & $\begin{array}{l}0.0069 \\
(2.27)\end{array}$ & $\begin{array}{l}0.0080 \\
(2.45)\end{array}$ \\
\hline DISC & & & & & $\begin{array}{l}-0.0063 \\
(-0.36)\end{array}$ \\
\hline$L I B$ & & & & & $\begin{array}{l}0.0506 \\
(1.26)\end{array}$ \\
\hline Constant & $\begin{array}{c}-0.0201 \\
(-1.85)\end{array}$ & & $\begin{array}{c}-0.0228 \\
(-1.88)\end{array}$ & $\begin{array}{c}-0.1320 \\
(-1.24)\end{array}$ & $\begin{array}{c}-0.2618 \\
(-1.82)\end{array}$ \\
\hline Country effects & & Fixed & Random & Random & Random \\
\hline$N$ & 641 & 641 & 641 & 551 & 529 \\
\hline Number of countries & 48 & 48 & 48 & 42 & 40 \\
\hline$R^{2}$ & 0.04 & 0.02 & 0.04 & 0.05 & 0.06 \\
\hline
\end{tabular}

Estimates of coefficients of the annual time-series cross-sectional regression at the country level of

$$
\begin{aligned}
\theta_{i, t}= & b_{0}+b_{1} \text { ENFORCE }_{i, t}+b_{11} \text { EMERGE }_{i, t}+b_{12} \text { ENFORCE }_{i, t} \times \text { EMERGE }_{i, t} \\
& +b_{2} \text { GOOD }_{i, t}+b_{3} \text { GDP }_{i, t}+b_{4} \text { NSTOCK }_{i, t}+b_{5} \text { IHERF }_{i, t}+b_{6} \text { FHERF }_{i, t} \\
& +b_{7} \text { VGDP }_{i, t}+b_{8} \text { SIZE }_{i, t}+b_{9} \text { DISC }_{i, t}+b_{10} \text { LIB }_{i, t}+\epsilon_{i, t}
\end{aligned}
$$

are shown where $\theta$ is the median annual information flow measure of Llorente et al. (2002) across all firms in each country in each year. ENFORCE is a dummy variable that takes the value of one in the year of the country's first insider trading enforcement case and thereafter, and zero otherwise. EMERGE is a dummy variable that takes the value of one if the country is an emerging market. GOOD is an index of the country's government respect for private property rights. Low values indicate less respect for private property. GDP is the logarithm of the gross domestic product per capita in US dollars for each country in each year. NSTOCK is the logarithm of the number of listed firms in each country in each year. IHERF is the industry Herfindahl index calculated using two-digit SIC industry sales for each country in each year. FHERH is the firm Herfindahl index calculated using individual firm sales for each country in each year. VGDP is the sample variance of the annual GDP per capita growth estimated using a five-year moving window for each country in each year. SIZE is the logarithm of the geographic size in square kilometers. DISC is a score for the country's level of accounting transparency. LIB is a dummy variable that takes the value of one in the country's official financial liberalization year and thereafter, and zero otherwise. Regressions include alternatively country fixed or random effects. The sample period is from 1990 to 2003. Robust $t$-statistics are in parentheses.

\section{markets. ${ }^{9}$ We also estimate separate regressions (results not tabulated here) for the sample of developed and emerging markets and find similar results.}

9 This regression is restricted to a shorter sample period (1990-2003) than the firm-specific return variation regressions (1980-2003) because of the lack of availability of international volume data. This could explain why coefficients are estimated with less precision. 
We further confirm our interpretation of firm-specific return variation as a measure of stock price informativeness by considering the relation between initial enforcement actions and a measure of the extent to which stock prices incorporate information about future earnings. If firm-specific return variation is a sign of information being incorporated into stock prices via trading by informed market participants, a stock price will track more closely its fundamental value and incorporate more information about future earnings. Durnev et al. (2003) define price informativeness as how much information about future earnings is embedded in stock prices, and find that this measure is positively correlated with firm-specific return variation.

Following Durnev et al. (2003), we estimate the future earnings return coefficient $(F E R C)$ for each year around the enforcement date within each country (with at least 10 firms). There are some missing observations, so we are able to estimate FERC around only 20 enforcement events (instead of 25): 13 in developed markets and 7 in emerging markets.

We estimate event-study regressions of FERC around the enforcement event using a three-year window, excluding the year of the enforcement (results not tabulated here). We find results consistent with our primary findings. Stock prices in developed markets incorporate more information about future earnings following first-time enforcement of insider trading laws (ENFORCE coefficient of 0.1942 with a $t$-statistic of 1.98). Moreover, there are different reactions to the enforcement of insider trading laws in emerging markets versus developed markets. The interaction variable is negative $(-0.5780)$ and significant $(t$-statistic of -2.77). Thus, stock prices in emerging markets are not more informative about future earnings, and there is even evidence that $F E R C$ drops after the enforcement of insider trading restrictions.

\subsection{Simulation of firm-specific stock return variation}

Insider trading is directly related to the speed of incorporation of new information into stock prices. Indeed, tests of the reaction of stock prices to news announcements focus on the preannouncement drift that shows the leaking of information prior to an announcement day [e.g., earnings announcements as in Ball and Brown (1968) and stock splits as in Fama et al. (1969)].

We develop a simulation intended to show that our proxy for price informativeness captures these dynamics adequately. This simulation shows there is greater firm-specific stock return variation when a return shock is timely incorporated into stock prices, which corresponds to higher stock price informativeness. There is less firm-specific return variation when a return shock is smoothed out over time, which corresponds to lower stock price informativeness.

The simulation studies the impact on relative firm-specific stock return variation, $\sigma_{e} / \sigma$ (or $1-R^{2}$ ), of an information release, such as an earnings announcement. We consider two alternative scenarios as to the speed of incorporation of this idiosyncratic shock into the stock price. We first assume the stock is 
subject to intense information collection and trading by outsiders, and so the shock is immediately incorporated into stock prices. This scenario is more likely to occur after the enforcement of insider trading laws as outsiders are more likely to acquire information. The second scenario assumes that the shock is incorporated slowly into stock prices, as there is little information collection and trading by outsiders. This scenario is more likely to occur when insiders are not barred from trading.

We expect greater relative firm-specific stock return variation in the first scenario (immediate incorporation) than in the second scenario (slow incorporation). Overall, the simulation results are consistent with our findings (see details in the Appendix): Insider trading restrictions lead to more efficient stock prices, as information is timely incorporated in stock prices, and firm-specific return variation is higher.

\section{Relation Between Cost of Equity and Enforcement and Information}

Finally, we address two questions. Does price informativeness contribute to a reduction in the cost of equity? How can we explain the paradox that prices do not become more informative in emerging markets but the cost of equity mainly declines in these same markets?

To address these questions, we estimate a cost of equity regression equation (with country fixed effects):

$$
K_{i, t}=d_{0}+d_{1} \text { ENFORCE }_{i, t}+d_{2} \Psi_{i, t}+d_{3} \text { ZEROS }_{i, t}+d_{4} L I B_{i, t}+\epsilon_{i, t},
$$

where $K_{i, t}$ is the dividend yield of country $i$ in month $t$, and ZEROS is the proportion of zero returns of country $i$ in month $t$. We use the dividend yield as a proxy for the country's cost of capital following Bekaert and Harvey (2000) and Bhattacharya and Daouk (2002). The dividend yield data come from Datastream; we use the dividend yield associated with each country's stock market index. ${ }^{10}$

Table 9 presents estimates of alternative specifications of the regression Equation (11). Column (1) replicates the result in Bhattacharya and Daouk (2002) for our extended sample period (1980-2003). Our point estimate of the ENFORCE coefficient implies a reduction in the annual cost of equity of $9 \%(=0.75 \% \times 12)$ as compared with $7 \%$ in Bhattacharya and Daouk (2002). Column (2) controls for the effect of liberalization, which does not significantly impact our estimate of the ENFORCE coefficient.

In column (3) of Table 9, we extend previous evidence by including the effect of stock price informativeness in the relation between cost of equity and enforcement. There is a negative and significant relation between the cost of equity and firm-specific return variation. This is evidence that an improvement

10 There are several advantages of using the dividend yield as a proxy for the cost of equity. For a detailed discussion of the relation between dividend yield and cost of equity, see Bekaert and Harvey (2000). 
Table 9

Relation between cost of equity and the enforcement of insider trading laws and information

(5) 2 SLS

(6) 2 SLS

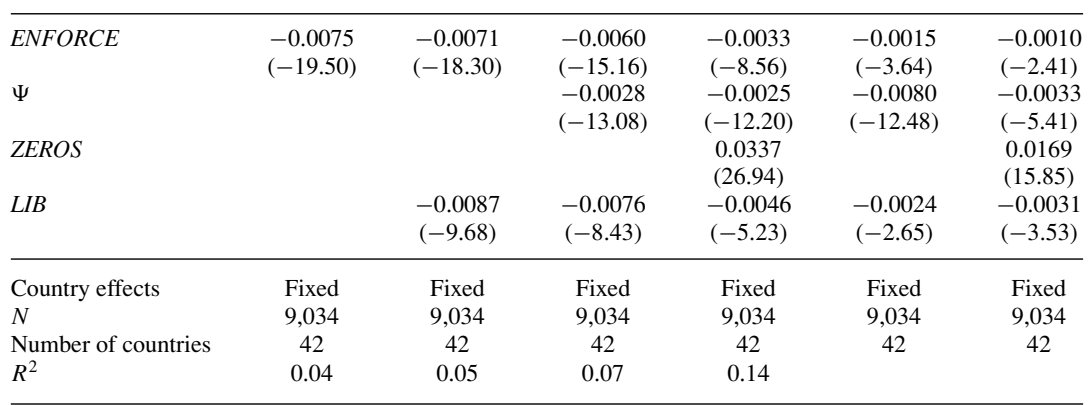

Estimates of coefficients of the monthly time-series cross-sectional regression at the country level of

$$
K_{i, t}=d_{0}+d_{1} \text { ENFORCE }_{i, t}+d_{2} \Psi_{i, t}+d_{3} \text { ZEROS }_{i, t}+d_{4} \text { LIB }_{i, t}+\epsilon_{i, t}
$$

are shown where $K$ is the cost of equity proxied by the dividend yield for each country in each month. ENFORCE is a dummy variable that takes the value of one in the year of the country's first insider trading enforcement case and thereafter, and zero otherwise. $\Psi$ is the median logistic transformed relative firm-specific stock return variation estimated using an international two-factor model for US dollar excess returns across all firms for each country in each year. ZEROS is the proportion of zero daily returns across all firms for each country averaged over the month. $L I B$ is a dummy variable that takes the value of one in the country's official financial liberalization year and thereafter, and zero otherwise. The regressions in columns (5) and (6) are estimated using two-stage least squares (2SLS). The instruments for firm-specific return variation $\Psi$ are the predetermined variables used in the $\Psi$ regressions equation (8): GOOD, GDP, NSTOCK, IHERF, FHERF, VGDP, SIZE, and DISC. The sample period is from 1980 to 2003. Robust $t$-statistics are in parentheses.

in price informativeness contributes to a decline in the cost of equity. The ENFORCE coefficient drops (but remains statistically significant), which supports a conclusion that price informativeness partially explains the reduction in the cost of equity associated with the enforcement of insider trading laws that we have documented.

Thus, we find that enhanced price informativeness reduces the cost of equity. This finding, however, does not explain why the cost of equity declines mainly in emerging markets, as we do not find an improvement in price informativeness in these markets.

In the Easley and O'Hara (2004) model, it is not only the quantity of information that affects the costs of capital but also its quality, particularly the distribution between public and private information. In this case, the cost of capital is an increasing function of private information. Our evidence, which is consistent with the Easley and O'Hara (2004) model prediction, reconciles our findings with the decline in the cost of equity (mainly in emerging markets) documented by Bhattacharya and Daouk (2002).

To measure liquidity costs and the probability of trading against informed agents, we use the proportion of zero returns, as in Lesmond, Ogden, and Trzcinka (1999). Their main hypothesis is that the marginal trader will trade on new information (not yet reflected in the price of a security) only if the 
value of that information exceeds the marginal costs of trading. Zero-return days are interpreted as days when there is not enough information available for the marginal investor to exceed the costs of trading. ${ }^{11}$

To calculate the country's proportion of zero returns, we use daily individual stock return data from Datastream. In each month, we compute the percentage of days that an individual stock has zero returns. The monthly $Z E R O$ variable is then calculated using the average of the proportion of zero-return days of all stocks in each country-month.

Column (4) of Table 9 includes the proportion of zero returns as an additional explanatory variable. The ENFORCE coefficient remains negative and significant, although about half the size as before. More important, there is a positive relation between the proportion of zero returns and the cost of equity. A lower proportion of zero returns reflects less information asymmetry between insiders and outsiders. This makes outsiders more willing to trade on new information, and reduces the cost of capital.

To examine whether there has been a change in the probability of informed trading around the enforcement, we perform an event study analysis that compares the average levels of the proportion of zero returns before and after the enforcement date. Figure 3 shows the proportion of zero returns in the threeyear period before and after a country's first-time enforcement of insider trading laws (excluding the year of the enforcement) for all countries where enforcement started during the sample period (1980-2003): 15 events in developed markets, and 10 events in emerging markets.

Not surprisingly, there is a higher average proportion of zero returns in emerging markets than in developed markets. On average, the proportion of zero returns declines from 0.2804 to 0.2561 in developed markets and from 0.3701 to 0.3023 in emerging markets. Thus, there is a lower proportion of zero returns around the time of enforcement of insider trading laws, especially in emerging markets. ${ }^{12}$

Our interpretation is that a lower probability of trading against insiders justifies fewer zero-return days and a lower risk premium. Following the enforcement of insider trading laws, the important role that insiders play in disseminating information that may affect prices is eroded in emerging markets, and marginal traders are now more willing to trade on new information, as they are less worried about the probability of trading against an insider.

These results provide a way to reconcile our finding that the enforcement of insider trading laws does not improve price informativeness in emerging markets and the finding of a reduced cost of equity documented in Bhattacharya

11 Alternative measures of liquidity costs include the effective bid-ask spread, the probability of informed trading (PIN) of Easley and O'Hara (2004), and the illiquidity of Amihud (2002). These measures, however, require transaction or volume data, which are of poor quality and are not widely available, especially in emerging markets. Bekaert, Harvey, and Lundblad (2007) find that the proportion of zero returns is a better measure of liquidity costs in emerging markets and captures aspects of liquidity that are not contained in turnover.

12 Analysis of alternative event windows including the one-year or two-year periods before and after the enforcement date provides similar evidence. 


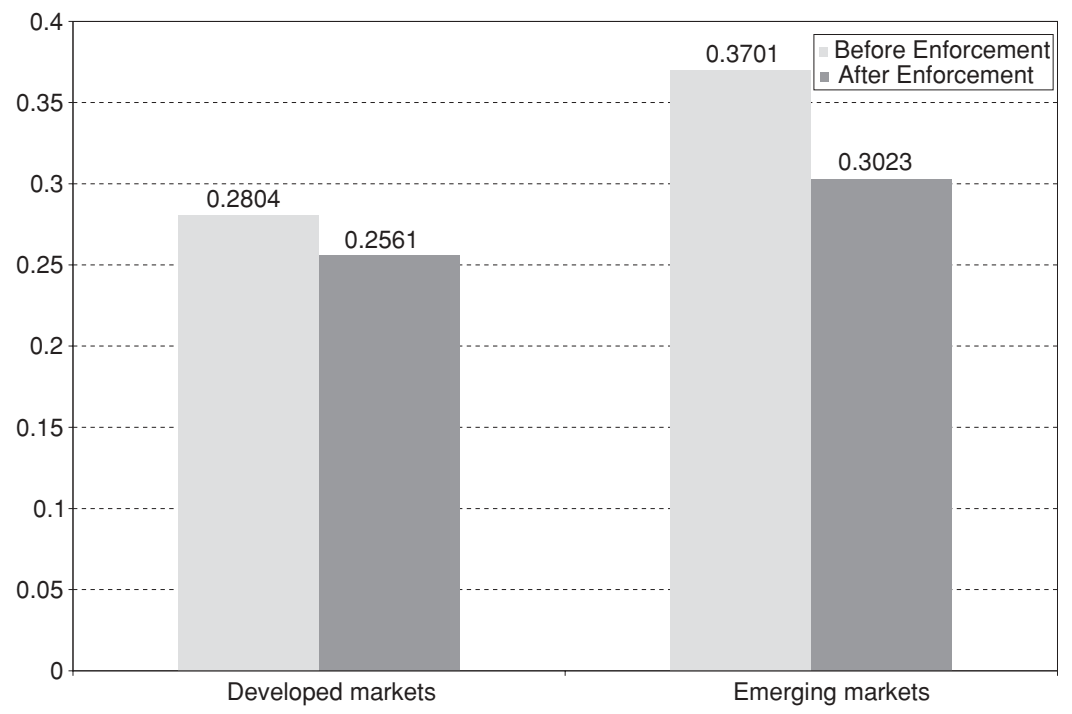

Figure 3

Proportion of zero returns around the enforcement of insider trading laws

This figure plots the average proportion of zero returns in the period before and after the enforcement in developed and emerging markets. The event window includes the three-year period before and after the enforcement year, excluding the year of the enforcement. The proportion of zero returns is the monthly average of the proportion of zero daily returns across all firms for each country.

and Daouk (2002). Enforcement in emerging markets seems to improve mainly the quality of information (a reduced probability of informed trading), but not the overall quantity of information (no change in price informativeness). Overall, the effect of the enforcement in emerging markets is to turn some private information into public information, thereby reducing the adverse selection problem of uninformed investors trading with informed investors and also the risk premium demanded by uninformed investors in emerging markets.

The last two columns in Table 9 address the potential endogeneity of a country's price informativeness. We provide evidence of an independent effect of firm-specific return variation on the cost of equity applying a two-stage least-squares procedure. We consider the predetermined variables in the firmspecific return regression Equation (8) as instruments. The results in columns (5) and (6) confirm that the exogenous variation in firm-specific return variation is significantly related to the cost of equity. As before, we find a positive and significant relation between cost of equity and the proportion of zero returns.

\section{Conclusion}

To examine the impact of initiating enforcement of insider trading laws on stock price informativeness, we use a large sample of developed and emerging markets over 1980-2003, when many countries started to enforce insider trading 
laws. The primary dependent variable is firm-specific stock return variation (or lack of synchronicity in stock returns). Other evidence supports the idea that firm-specific return variation captures the extent to which information about a firm is quickly and accurately impounded in stock prices. We present simulation-based results that confirm this interpretation of firm-specific return variation.

Our primary findings reveal that enforcement of insider trading laws can have different effects on stock price informativeness around the world. There is a strong asymmetric relationship between enforcement and stock price informativeness with respect to a country's level of development and its quality of legal institutions. Enforcement is associated with higher firm-specific return variation in developed markets; the reverse is true for emerging markets. Our results actually suggest that the enforcement of insider trading laws in emerging markets has an insignificant (or even negative) effect on firm-specific return variation.

Analysis of the source of this asymmetry across developed and emerging markets indicates that the quality of macro infrastructures matters. Indeed, improvements in stock price informativeness following the enforcement of insider trading laws are concentrated in markets that provide strong protection for shareholder rights, efficient legal systems, and good disclosure of information. The enforcement of insider trading laws in fact diminishes stock price informativeness in countries that rank low on these criteria. In this case, insiders play an important role in impounding information into stock prices, and this role is largely eroded upon enforcement.

The negative relation documented in Bhattacharya and Daouk (2002) between cost of equity and enforcement is in part explained by stock price informativeness. The decline in the cost of equity in emerging markets is explained by a change in the quality of information (a reduction in the probability of informed trading) rather than a change in the quantity of information. Indeed, the enforcement is able to turn some private information into public information in emerging markets, which contributes to a drop in the cost of equity.

These results add considerably to the debate on the complementary role of macro infrastructures. In countries with poor infrastructure, the enforcement of insider trading laws does not by itself achieve the goal of improving a country's information environment. That is, it is not enough to bar trading by insiders. Other complementary policy measures must be undertaken before outside investors will be willing to devote resources to the production of firmspecific information.

\section{Appendix: Simulation of Firm-Specific Stock Return Variation}

We simulate relative firm-specific return variation, $\sigma_{e} / \sigma$ (or $1-R^{2}$ ), under two alternative scenarios for the speed of incorporation of an idiosyncratic shock into stock prices: (1) the shock is 
immediately incorporated into stock prices (one period), as there is intense information collection and trading by outsiders; (2) the shock is slowly incorporated into stock prices, as there is little information collection and trading by outsiders.

\section{Definitions}

Let the horizon be given by $T-t=1$ year, the number of time steps be given by $n=260$, and the length of each time step $\Delta t=1 / 260$.

The data-generating process for excess market return is given by

$$
r_{m t}=\mu_{m} \Delta t+\sigma_{m} \sqrt{\Delta t} \widetilde{\varepsilon}_{m t},
$$

where $\widetilde{\varepsilon}_{m t} \sim N(0,1), \mu_{m}$ is the annual market risk premium, and $\sigma_{m}$ is the annual market standard deviation.

The data-generating process for excess stock return given by the CAPM, is given by

$$
r_{i t}=\beta_{i} r_{m t}+\sigma_{\varepsilon_{i}} \sqrt{\Delta t} \widetilde{\varepsilon}_{i t}
$$

where $\left.\widetilde{\varepsilon}_{i t} \sim N(0,1), \operatorname{Cov} \widetilde{\varepsilon}_{m t}, \widetilde{\varepsilon}_{i t}\right)=0, \beta_{i}$ is the stock beta, and $\sigma_{\varepsilon_{i}}$ is the annual stock idiosyncratic standard deviation.

We define an idiosyncratic shock to stock return as $\Delta$, which can be incorporated in one period or in $K$ periods with the shock equally divided by each period.

\section{Algorithm}

1. Generate $\widetilde{\varepsilon}_{m t}$ and $\widetilde{\varepsilon}_{i t}$ for $t=1,2, \ldots, n$.

2. Calculate $r_{m t}$ using Equation (A1) for $t=1,2, \ldots, n$.

3. Calculate $r_{i t}$ using Equation (A2) for $t=1,2, \ldots, n$.

4. Calculate $1-R_{m}^{2}$ of regression of $r_{i t}$ on $r_{m t}$.

5. Generate $\tilde{\tau} \in[1, n-K]$ using an uniform distribution.

6. Calculate $r_{i t}^{*}=r_{i t}+\Delta$ for $t=\tilde{\tau}$, and $r_{i t}^{*}=r_{i t}$ for $t \neq \tilde{\tau}$.

7. Calculate $r_{i, t}^{* *}=r_{i, t}+\frac{\Delta}{K}$ for $t=\tilde{\tau}, \tilde{\tau}+1, \ldots, \tilde{\tau}+K-1$, and $r_{i t}^{* *}=r_{i t}$ for $t \neq \tau, \tau+$ $1, \ldots, \tau+K$.

8. Calculate $1-R_{m *}^{2}$ of regression of $r_{i t}^{*}$ on $r_{m t}$.

9. Calculate $1-R_{m * *}^{2}$ of regression of $r_{i t}^{* *}$ on $r_{m t}$.

10. Repeat steps 1-9 $M$ times.

11. Calculate estimate of $1-R^{2}$ as $1-\bar{R}^{2}=\frac{1}{M} \sum_{m=1}^{N}\left(1-R_{m}^{2}\right)$ [base case in column (1)]. ${ }^{13}$

12. Calculate average of $1-R_{*}^{2}$ as $1-\bar{R}_{*}^{2}=\frac{1}{M} \sum_{m=1}^{N}\left(1-R_{m *}^{2}\right)$ [immediate incorporation case in column (2)].

13. Calculate average of $1-R_{* *}^{2}$ as $1-\bar{R}_{* *}^{2}=\frac{1}{M} \sum_{m=1}^{N}\left(1-R_{m * *}^{2}\right)$ [slow incorporation case in column (3)].

13 There is an analytical solution for the base case given by $1-R^{2}=1-\frac{\beta_{i}^{2} \sigma_{m}^{2}}{\beta_{i}^{2} \sigma_{m}^{2}+\sigma_{\varepsilon_{i}}^{2}}$. 
Simulation results $(M=100,000)$

Simulated

\begin{tabular}{|c|c|c|c|c|c|c|c|c|c|c|}
\hline \multirow{2}{*}{\multicolumn{6}{|c|}{ Parameters }} & \multirow{3}{*}{$\frac{\text { Analytical }}{1-R^{2}}$} & \multirow{3}{*}{$\frac{(1)}{1-R^{2}}$} & \multirow{3}{*}{$\begin{array}{c}(2) \\
1-R_{*}^{2}\end{array}$} & \multirow{3}{*}{$\begin{array}{c}\text { (3) } \\
1-R_{* *}^{2}\end{array}$} & \multirow{3}{*}{$\begin{array}{c}(4)=(2)-(3) \\
\text { Difference }\end{array}$} \\
\hline & & & & & & & & & & \\
\hline$\mu_{m}$ & $\sigma_{m}$ & $\beta_{i}$ & $\sigma_{\varepsilon_{i}}$ & $\Delta$ & $K$ & & & & & \\
\hline 0.06 & 0.20 & 1.0 & 0.22 & 0.08 & 60 & 0.5475 & 0.5473 & 0.5778 & 0.5477 & 0.0301 \\
\hline 0.06 & 0.20 & 1.5 & 0.22 & 0.08 & 60 & 0.3497 & 0.3502 & 0.3790 & 0.3506 & 0.0283 \\
\hline 0.06 & 0.20 & 0.5 & 0.22 & 0.08 & 60 & 0.8288 & 0.8268 & 0.8437 & 0.8271 & 0.0166 \\
\hline 0.06 & 0.20 & 1.0 & 0.35 & 0.08 & 60 & 0.7539 & 0.7523 & 0.7616 & 0.7525 & 0.0092 \\
\hline 0.06 & 0.20 & 1.0 & 0.15 & 0.08 & 60 & 0.3600 & 0.3605 & 0.4198 & 0.3614 & 0.0585 \\
\hline 0.06 & 0.20 & 1.0 & 0.22 & 0.10 & 60 & 0.3600 & 0.3604 & 0.4485 & 0.3617 & 0.0868 \\
\hline 0.06 & 0.20 & 1.0 & 0.22 & 0.04 & 60 & 0.5475 & 0.5474 & 0.5554 & 0.5475 & 0.0079 \\
\hline 0.06 & 0.20 & 1.0 & 0.22 & 0.08 & 100 & 0.5475 & 0.5473 & 0.5777 & 0.5475 & 0.0302 \\
\hline 0.06 & 0.20 & 1.0 & 0.22 & 0.08 & 30 & 0.5475 & 0.5473 & 0.5776 & 0.5482 & 0.0294 \\
\hline
\end{tabular}

The results confirm our hypothesis that when an idiosyncratic shock to the stock return process is incorporated more quickly into stock prices via informed arbitrage, there is greater relative firm-specific stock return variation than when the shock is slowly incorporated (i.e., $1-R_{*}^{2}>1-R_{* *}^{2}$ ). Column (4) shows the difference in relative firm-specific return variation between these two scenarios. Using different parameters (e.g., size of the shock, timing of incorporation), there is always higher firm-specific risk relative to total risk when information is incorporated in a timely fashion [see column (2)] than when it is incorporated slowly [see column (3)].

\section{References}

Ackerman, A., and E. Maug. 2006. Insider Trading Legislation and Acquisition Announcements: Do Laws Matter? Working Paper, University of Mannheim.

Amihud, Y. 2002. Illiquidity and Stock Returns: Cross-Section and Time-Series Effects. Journal of Financial Markets 5:31-56.

Ausubel, L. 1990. Insider Trading in a Rational Expectations Economy. American Economic Review 80: $1022-41$.

Ball, R. 2001. Infrastructure Requirements for an Economically Efficient System of Public Financial Reporting and Disclosure. Brookings Papers on Financial Services:127-169.

Ball, R., and P. Brown. 1968. An Empirical Evaluation of Accounting Income Numbers. Journal of Accounting Research 6:159-78.

Bekaert, G., and C. Harvey. 2000. Foreign Speculators and Emerging Equity Markets. Journal of Finance 55:565-613.

Bekaert, G., C. Harvey, and C. Lundblad. 2005. Does Financial Liberalization Spur Growth? Journal of Financial Economics 77:3-55.

Bekaert, G., C. Harvey, and C. Lundblad. 2007. Liquidity and Expected Returns: Lessons from Emerging Markets. Review of Financial Studies 20:1783-1831.

Bhattacharya, U., and H. Daouk. 2002. The World Price of Insider Trading. Journal of Finance 573: 75-108.

Bhattacharya, U., and H. Daouk. 2005. When No Law Is Better Than a Good Law. Working Paper, Indiana University.

Bhattacharya, U., H. Daouk, B. Jorgenson, and C.-H. Kehr. 2000. When an Event Is Not an Event: The Curious Case of an Emerging Market. Journal of Financial Economics 55:69-101.

Bushman, R., J. Piotroski, and A. Smith. 2005. Insider Trading Restrictions and Analysts' Incentives to Follow Firms. Journal of Finance 60:35-66.

Carlton, D., and D. Fischel. 1983. The Regulation of Insider Trading. Stanford Law Review 35:857-95. 
Chakravarty, S., and J. McConnell. 1999. Does Insider Trading Really Move Stock Prices? Journal of Financial and Quantitative Analysis 34:191-209.

Chan, K., and A. Hameed. 2006. Stock Price Synchronicity and Analyst Coverage in Emerging Markets. Journal of Financial Economics 80:115-47.

Chen, Q., I. Goldstein, and W. Jiang. 2007. Price Informativeness and Investment Sensitivity to Stock Price. Review of Financial Studies 20:619-50.

Dasgupta, S., J. Gan, and N. Gao. 2006. Lumpy Information Disclosure and Stock Return Synchronicity: Evidence from ADR Listings. Working Paper, Hong Kong University of Science and Technology.

Durnev, A., R. Morck, and B. Yeung. 2004. Value-Enhancing Capital Budgeting and Firm-Specific Stock Return Variation. Journal of Finance 59:65-105.

Durnev, A., R. Morck, B. Yeung, and P. Zarowin. 2003. Does Greater Firm-Specific Return Variation Mean More or Less Informed Stock Pricing? Journal of Accounting Research 41:797-836.

Easley, D., and M. O'Hara. 2004. Information and the Cost of Capital. Journal of Finance 59:1553-83.

Easley, D., M. O'Hara, and J. Paperman. 1998. Financial Analysts and Information-Based Trade. Journal of Financial Markets 1:175-201.

Fama, E., L. Fisher, M. Jensen, and R. Roll. 1969. The Adjustment of Stock Prices to New Information. International Economic Review 10:1-21.

Fishman, M., and K. Hagerty. 1992. Insider Trading and the Efficiency of Stock Prices. Rand Journal of Economics 23:106-22.

French, K., and R. Roll. 1986. Stock Return Variances: The Arrival of Information and the Reaction of Traders. Journal of Financial Economics 17:5-26.

French, K., G. W. Schwert, and R. Stambaugh. 1987. Expected Stock Returns and Volatility. Journal of Financial Economics 19:3-30.

Grossman, S., and J. Stiglitz. 1980. On the Impossibility of Informationally Efficient Markets. American Economic Review 70:393-408.

Jin, L., and S. Myers. 2006. $R^{2}$ Around the World: New Theory and New Tests. Journal of Financial Economics 79:257-92.

La Porta, R., F. Lopez-de-Silanes, A. Shleifer, and R. Vishny. 1998. Law and Finance. Journal of Political Economy 106:1113-55.

Leland, H., 1992, Insider Trading: Should It Be Prohibited? Journal of Political Economy 100:859-87.

Lesmond, D., J. Ogden, and C. Trzcinka. 1999. A New Estimate of Transaction Costs. Review of Financial Studies 12:1113-41.

Li, K., R. Morck, F. Yang, and B. Yeung. 2004. Firm-Specific Variation and Openness in Emerging Markets. Review of Economics and Statistics 86:658-69.

Llorente, G., R. Michaely, G. Saar, and J. Wang. 2002. Dynamic Volume-Return Relation of Individual Stocks. Review of Financial Studies 15:1005-47.

Manne, H. 1966. Insider Trading and the Stock Market. New York: Free Press.

Manove, M. 1989. The Harm from Insider Trading and Informed Speculation. Quarterly Journal of Economics 104:823-45.

Morck, R., B. Yeung, and W. Yu. 2000. The Information Content of Stock Markets: Why Do Emerging Markets Have Synchronous Stock Price Movements? Journal of Financial Economics 58:215-60.

Petersen, M. 2007. Estimating Standard Errors in Finance Panel Data Sets: Comparing Approaches. Review of Financial Studies, forthcoming. 
Piotroski, J., and D. Roulstone. 2004. The Influence of Analysts, Institutional Investors, and Insiders on the Incorporation of Market, Industry, and Firm-Specific Information into Stock Prices. Accounting Review 79:1119-51.

Roll, R. 1988. $R^{2}$. Journal of Finance 43:541-66.

Scholes, M., and J. Williams. 1977. Estimating Betas from Nonsynchronous Data. Journal of Financial Economics 5:309-28.

Wurgler, J. 2000. Financial Markets and the Allocation of Capital. Journal of Financial Economics 58:187-214. 